\title{
The Interplay of Hypoxia Signaling on Mitochondrial Dysfunction and Inflammation in Cardiovascular Diseases and Cancer: From Molecular Mechanisms to Therapeutic Approaches
}

\author{
Esmaa Bouhamida ${ }^{1,2}$, Giampaolo Morciano ${ }^{1,2}$, Mariasole Perrone ${ }^{1} \mathbb{D}$, Asrat E. Kahsay ${ }^{1}$, Mario Della Sala ${ }^{1}$, \\ Mariusz R. Wieckowski ${ }^{3}(\mathbb{D})$, Francesco Fiorica ${ }^{4}\left(\mathbb{D}\right.$, Paolo Pinton ${ }^{1,2}\left(\mathbb{D}\right.$, Carlotta Giorgi ${ }^{1, *(D)}$ \\ and Simone Patergnani ${ }^{1,2, *(D)}$
}

check for updates

Citation: Bouhamida, E.; Morciano, G.; Perrone, M.; Kahsay, A.E.; Della Sala, M.; Wieckowski, M.R.; Fiorica, F.; Pinton, P.; Giorgi, C.; Patergnani, S. The Interplay of Hypoxia Signaling on Mitochondrial Dysfunction and Inflammation in Cardiovascular Diseases and Cancer: From

Molecular Mechanisms to Therapeutic Approaches. Biology 2022, 11, 300. https://doi.org/ 10.3390/biology11020300

Academic Editor: Nathan Lanning

Received: 4 January 2022

Accepted: 9 February 2022

Published: 12 February 2022

Publisher's Note: MDPI stays neutral with regard to jurisdictional claims in published maps and institutional affiliations.

Copyright: (c) 2022 by the authors Licensee MDPI, Basel, Switzerland. This article is an open access article distributed under the terms and conditions of the Creative Commons Attribution (CC BY) license (https:// creativecommons.org/licenses/by/ $4.0 /)$.
1 Department of Medical Sciences and Laboratory for Technologies of Advanced Therapies (LTTA), University of Ferrara, 44121 Ferrara, Italy; bhmsme@unife.it (E.B.); mrcgpl@unife.it (G.M.); prrmsl@unife.it (M.P.); khsstn@unife.it (A.E.K.); mario.dellasala@unife.it (M.D.S.); paolo.pinton@unife.it (P.P.)

2 Translational Research Center, Maria Cecilia Hospital GVM Care \& Research, 48022 Cotignola, Italy

3 Laboratory of Mitochondrial Biology and Metabolism, Nencki Institute of Experimental Biology of the Polish Academy of Sciences, 02-093 Warsaw, Poland; m.wieckowski@nencki.edu.pl

4 Department of Radiation Oncology and Nuclear Medicine, AULSS 9 Scaligera, Ospedale Mater Salutis di Legnago, 37045 Verona, Italy; francesco.fiorica@aulss9.veneto.it

* Correspondence: carlotta.giorgi@unife.it (C.G.); simone.patergnani@unife.it (S.P.)

Simple Summary: The regulation of hypoxia has recently emerged as having a central impact in mitochondrial function and dysfunction in various diseases, including the major disorders threatening worldwide: cardiovascular diseases and cancer. Despite the studies in this matter, its effective role in protection and disease progression even though its direct molecular mechanism in both disorders is still to be elucidated. This review aims to cover the current knowledge about the effect of hypoxia on mitochondrial function and dysfunction, and inflammation, in cardiovascular diseases and cancer, and reports further therapeutic strategies based on the modulation of hypoxic pathways.

\begin{abstract}
Cardiovascular diseases (CVDs) and cancer continue to be the primary cause of mortality worldwide and their pathomechanisms are a complex and multifactorial process. Insufficient oxygen availability (hypoxia) plays critical roles in the pathogenesis of both CVDs and cancer diseases, and hypoxia-inducible factor 1 (HIF-1), the main sensor of hypoxia, acts as a central regulator of multiple target genes in the human body. Accumulating evidence demonstrates that mitochondria are the major target of hypoxic injury, the most common source of reactive oxygen species during hypoxia and key elements for inflammation regulation during the development of both CVDs and cancer. Taken together, observations propose that hypoxia, mitochondrial abnormality, oxidative stress, inflammation in CVDs, and cancer are closely linked. Based upon these facts, this review aims to deeply discuss these intimate relationships and to summarize current significant findings corroborating the molecular mechanisms and potential therapies involved in hypoxia and mitochondrial dysfunction in CVDs and cancer.
\end{abstract}

Keywords: hypoxia; HIF-1 $\alpha$; mitochondria; oxidative stress; inflammation; cardiovascular diseases; cancer; therapeutic target

\section{Introduction}

Cardiovascular disease (CVD) and cancer are the major issues threatening public health globally and relatively widespread with enhanced morbidity and mortality. New strategies to improve their prevention and treatment are priorities worldwide. Besides, accumulating insights reported risk factors potentially linking both disorders such as 
environmental factors (obesity, tobacco, sedentary lifestyle, and diet), genetics, cellular, and signaling mechanisms [1]. Furthermore, a growing number of studies demonstrate that the incidence of CVDs risk is higher in patients with cancer disorders [2] and various ancillary processes correlated to CVDs have been identified to have a role in the pathogenesis of cancer $[3,4]$. Therefore, understanding the mechanism overlapping in these disorders paves the way to improve and elucidate putative therapeutic targets and preventative approaches, ultimately developing emerged cardio-oncology research.

Oxygen $\left(\mathrm{O}_{2}\right)$ delivery is an effective prerequisite to ensure the normal function of the cell and is fundamental for a wide range of physiological responses including, cell metabolism, and growth. $\mathrm{O}_{2}$ serves as an important for aerobic respiration that yields the primary cellular energy, the adenosine triphosphate (ATP) [5]. This process normally occurs at the powerhouse of $\mathrm{O}_{2}$ consumption in the cell, the mitochondria, mainly via oxidative phosphorylation (OXPHOS) and tricarboxylic acid (TCA). However, when $\mathrm{O}_{2}$ supply is insufficient to meet cellular energy demand, cells undergo hypoxia and are forced to use anaerobic respiration, which generates less than a tenth of the amount of aerobic respiration. Subsequently, mitochondria are severely affected by hypoxia, they sense the $\mathrm{O}_{2}$ levels and initiate cellular responses to hypoxia. Along with those lines, mitochondria are considered the key source of hypoxic damage in the human body [6]. Therefore, hypoxia introduces dysfunctional feedback resulting in mitochondrial damage that exacerbates oxidative stress and inflammatory signaling, correlating to mitochondrial metabolism upon hypoxia [7]. It is well known that hypoxia is a hallmark of various diseases. Indeed, at cellular levels, emerging evidence reported the pathophysiological of both CVDs and cancer disorder involve complicated and coordinated signaling pathways triggered during a decline of tissues or cells $\mathrm{O}_{2}$ stress (hypoxic milieu). We have selected to discuss both CVDs and cancer as major disorders characterized by the involvement of hypoxia in which most importantly has a crucial impact in promoting several processes, such as oxidative stress, inflammation, as well as cell death, and it is considered as one of the key common features with dual roles in both mentioned disorders [8].

In response to hypoxia, each cell displays numerous types of signals at the transcriptional and translational levels, consisting of the activation of a group of genes termed as hypoxic-inducible genes, which are involved in different biological processes, including cellular metabolism (lactate dehydrogenase-A (LDH-A) or pyruvate dehydrogenase kinase isoform 1 (PDK)) [9,10], angiogenesis (vascular endothelial growth factor-A (VGFA)) [11], erythropoiesis (erythropoietin (EPO)) [12], and inflammation (inducible nitric oxide synthase (iNOS)) [13].

Hypoxic-inducible factor-1 (HIF-1) is a central regulator mediating the cellular response in hypoxic conditions. It is composed of a heterodimer of constitutively expressed subunits, which are the $\mathrm{O}_{2}$-regulated subunits HIF- $\alpha$ and HIF- $\beta[14,15]$. Research of Gregg Semenza's laboratory at Johns Hopkins Medical Institutions led to HIF-1 exploration after discerning hypoxia response element (HRE), putative sequences in the $3^{\prime}$-flanking region of the human EPO gene. Further research found that the transcriptional activation of several regulatory genes is triggered by the binding of a particular protein to the HRE, which is induced by hypoxia. This protein was later identified as HIF-1 [16].

Over the last few decades, multiple pioneers of research on HIF- $1 \alpha$ have strikingly revolutionized the comprehension of the $\mathrm{O}_{2}$ balance. In fact, HIF- $1 \alpha$ has drawn much attention in many research fields, as it is outlined as the master $\mathrm{O}_{2}$ regulator within the cells, a hallmark transcriptional factor in the cellular response to a hypoxic environment, and a primary element for the regulation of several genes during hypoxic condition [17]. It is foreseeable that the disruption in hypoxia-related pathways contributes for several pathological states including CVDs as well as cancer, pointing out the key role of HIF-1 as a breaking point and a major cause specifically between both mentioned disorders [18].

This review aims to cover the actual comprehensions about the effect of hypoxiamediating signaling pathways on mitochondrial function, and inflammation in key human diseases such as CVDs and cancer. The complexity of these impacts will be examined in 
the light of recent studies that shall help us to better dissecting the molecular mechanism and designing potential therapeutic approaches against both disorders.

\section{Molecular Characteristic and Regulation of HIF-1}

In mammalian cells, HIF-1 has been demonstrated to play a fundamental impact in cellular and systemic $\mathrm{O}_{2}$ homeostasis [19], which mediates adaptation to hypoxia through activation of a multitude of genes encoding proteins needed for improving tissue $\mathrm{O}_{2}$ homeostasis, energy metabolism, and efficient management of hypoxia-induced toxic stress [20]. HIF-1 is a heterodimeric trans-acting DNA-binding transcription factor that constitutionally comprises expressed subunit HIF-1 $\beta$ (aryl hydrocarbon receptor nuclear translocator, ARNT) and an $\mathrm{O}_{2}$-sensitive expressed HIF- $1 \alpha$ subunit (or its analogues HIF- $2 \alpha$ and HIF- $3 \alpha$ ) a master transcriptional regulator in response to hypoxia and a key modulator for the induction of genes that facilitate adaptation and survival of cells [21]. Both subunits, $\alpha$ and $\beta$, exhibit basic helix-loop-helix (bHLH) motifs and belong to the bHLH-Per-ARNTSim (PAS) homology protein family. The bHLH domain is a DNA-binding domain that can bind HREs to target specific genes [22,23].

In normal conditions, the HIF- $1 \alpha$ subunit is hydroxylated by HIF prolyl-4-hydroxylases at proline 402 and 564 in the $\mathrm{O}_{2}$-dependent degradation domain (ODDD) of the $\alpha$-subunits, causing its ubiquitination and proteasomal destruction via the ubiquitin-proteasome (26S) mechanism, which is able to incite constantly the proteasomal degradation. Von HippelLindau (pVHL), which also acts as a tumor suppressor, binds the ubiquitin ligase complex E3, that targets HIF- $1 \alpha$ subunit destruction in $\mathrm{O}_{2}$-dependent degradation domain. Because of this, during normoxia HIF-1 $\alpha$ protein has a short half-life [24,25]. In contrast, under hypoxia, the repression of $\mathrm{O}_{2}$-dependent propyl-hydroxylase- $1,-2$, and -3 enzyme activity (PHD1, $-2,-3$ ) results in suppression of HIF-1 $\alpha$ hydroxylation. HIF-1 $\alpha$ protein is then stabilized, accumulates in the cytosol, and transferred into the nucleus, where it creates a heterodimer complex with HIF-1 $\beta$ and binds to HREs with a consensus sequence $\left(5^{\prime}\right.$-RCGTG-3') in promoter or enhancer of target genes to activate a concerted transcriptional response (Figure 1). The nuclear translocation of HIF-1 $\alpha$ is not enough to stimulate the target genes transcription [23]. The HIF-1 $\alpha / \mathrm{HIF}-1 \beta$ (HIF-1) transcription factor recruits various cofactors that are fundamental for full transcription activity, including CREB-binding protein (CBP)/p300 and transcription intermediary factor 2 steroid-receptor activator that ultimately binds to CTAD domain. Another cofactor recognized is the M2 isoform of pyruvate kinase (PKM2), which enhances the binding of the complex HIF-1 to HRE [26]. 


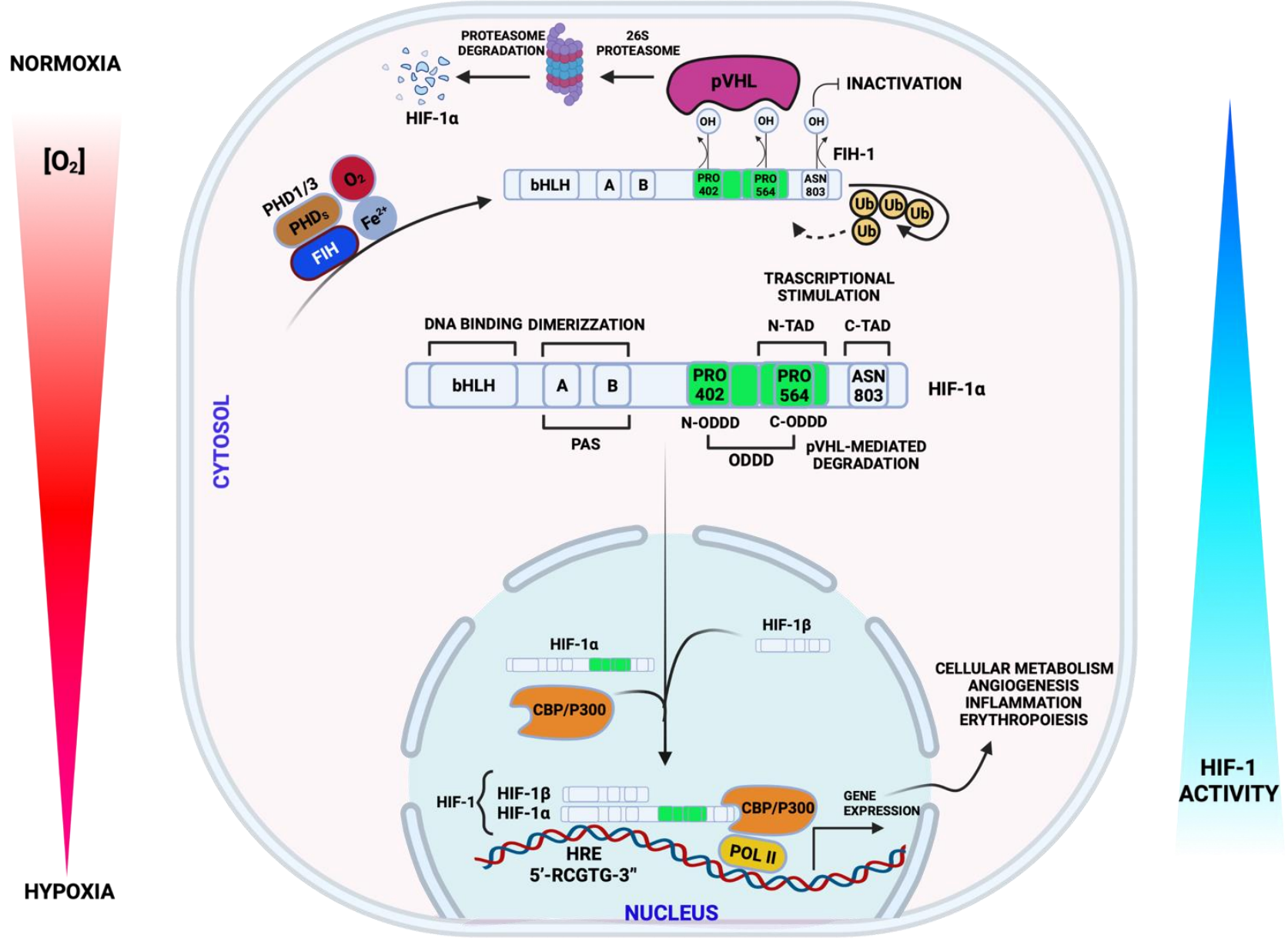

Figure 1. Schematic illustration representing the regulation of Hypoxic-inducible factor-1 $\alpha$ (HIF-1 $\alpha)$ protein in response to normoxia and hypoxia. During normoxia, HIF-1 $\alpha$ protein is hydroxylated by propyl-hydroxylases (PHDs) and factor inhibiting HIF (FIH). Both oxygen-dependent proteins are stimulated in normal condition and suppress HIF-1 $\alpha$ activity. The hydroxylated prolyl residues permit the binding of HIF-1 $\alpha$ by the von Hippel-Lindau protein (pVHL), resulting in ubiquitination and ultimate proteasomal destruction. During hypoxia or PHD inhibition, HIF-1 $\alpha$ moves to the nucleus, heterodimerizes with HIF- $1 \beta$, and subsequently binds to hypoxia response element (HRE) in the putative region of target gene to enhance their transcription.

\section{Role of Hypoxia Signaling and Mitochondria in Cardiovascular Diseases (CVDs) and Cancer}

\subsection{Hypoxia Signaling and Mitochondria in CVDs}

Hypoxia stimulates multiple processes to adapt to insufficient levels of $\mathrm{O}_{2}$ in the environment. Therefore, it has mostly negative consequences for cardiovascular functions, ultimately manifesting in pathology. HIF- $1 \alpha$ is an $\mathrm{O}_{2}$-sensitive transcription factor that regulates adaptive metabolic responses to hypoxia and elicits a crucial impact in various CVDs, such as ischemic heart disease (IHD) and heart failure (HF) [27]. Recent insights demonstrated the effect of HIF- $1 \alpha$ signaling in the progression of heart disorders [28,29], or its cardioprotective role after I/R in animal model deficient of PHD3 and HL-1 cardiomyocytes [30,31] (Figure 2). Furthermore, HIF-1 $\alpha$ overexpression caused mitigation of ischemia/reperfusion (I/R)-enhanced cardiomyocytes loss, suggesting that HIF-1 $\alpha$ may drastically influence cardiomyocytes endurance [32]. Recently, studies documented that the HIF signaling pathway not only stimulates disease progression but has a cardioprotective effect as well as the potential for cell recovery from cellular stress in various disorders. This seems to be linked to the duration of hypoxic exposure as well as the stabilization 
of HIF-1. In fact, chronic exposure to hypoxia is found to increase ischemic ventricular arrhythmias and further cell death [33]. While intermittent exposure to hypoxia reduces arrhythmia during $I / R$, as also stimulates protective effects against myocardial infarction in rodents [34-37]. The prolonged HIF- $1 \alpha$ upregulation was shown to promote dilated cardiomyopathy in transgenic mice with PHD2 depletion [38]. HIF-1 $\alpha$ can also influence mitochondrial function and alleviate the severity of ischemic heart. HIF- $1 \alpha$ can also influence mitochondrial function and alleviate the severity of ischemic heart. HIF- $1 \alpha$ can upregulate mitophagy, mitochondrial autophagy, in cardiac cells through HIF- $1 \alpha /(\mathrm{BNIP} 3)$ BCL2 and adenovirus E1B 19-kD-interacting protein 3 pathways, thereby stimulating their survival following myocardial ischemia-reperfusion. This is only applied to the role of HIF- $1 \alpha$-mediated mitophagy at an early phase of ischemia, which may result in cardiac protection, while prolonged autophagy may activate cell death in $\mathrm{H} 9 \mathrm{C} 2$ cardiomyoblasts and Sprague Dawley rat models [39]. In contrast, other studies revealed that HIF-1 activation enhances BNIP3 expression, resulting in (H9C2) cardiomyocyte death, which is a hallmark of ischemia and HF [40,41] (Table 1). Major interplays have been identified between hypoxia-mediated mitochondrial function and mitophagy in cardiomyocytes. In brief, upregulation of the inner mitochondrial membrane protein (IMM), Optic atrophy 1 (Opa1) stimulates mitophagy and mitochondrial function in response to hypoxia in mouse cardiomyocytes [42]. FUN14 Domain Containing 1 (FUNDC1) is an OMM protein that accumulates on the mitochondrial associated membranes (MAMs). Several recent studies reported its effective role to mediate mitophagy during ischemic conditions in cardiomyocytes, and it thus conveys cardioprotection [43]. Although the cardioprotective effect of mitophagy in the ischemic heart is widely demonstrated, during the reperfusion stage, mitophagy has a defective impact on cardiac function, and this may be due to the repression of FUNDC1-dependent mitophagy and necrosis upregulation [44]. The contribution of FUNDC1 in response to hypoxia may provide new insight in favor of therapeutic target approaches in CVDs, and further research focused on the FUNDC1-HIF-1 axis may be beneficial. Furthermore, a novel protein, WD Repeat Domain 26 (WDR26), has been detected to localize into the mitochondria, promoting mitophagy in $\mathrm{H} 9 \mathrm{C} 2$ cells during hypoxia, suggesting its pivotal effect in hypoxia-enhanced mitophagy [45]. In another line of evidence, HIF- $1 \alpha$ accumulation directs mitophagy and promotes the differentiation of $\mathrm{H} 9 \mathrm{C} 2$ cells [46]. Therefore, HIF-1 modulates hundreds of genes in diverse biological pathways, and most of them influence mitochondrial function. HIF-1 activates mitochondria-specific genes crucial to a metabolic shift away from OXPHOS to glycolysis, including LDH-A, phosphoglycerate kinase-1 (PGK1), to adapt to hypoxic stress [47]. HIF-1 elevates glycolysis by upregulating glycolysis enzyme production, increasing glucose transporters, and repressing the mitochondrial energy metabolism [18]. Moreover, HIF-1 $\alpha$ promotes PDK-1 activation, which phosphorylates and inhibits pyruvate dehydrogenase (PDH), from converting pyruvate to acetyl CoA to fuel the mitochondrial TCA cycle and preventing the formation of iron-sulfur ( $\mathrm{Fe} / \mathrm{S}$ ) clusters, thereby attenuating complex I activity [48]. It also inhibits the expression of mitochondrial encoded subunits in OXPHOS complexes by blocking the nuclear-mitochondrial interaction [49]. Recent pieces of evidence have also reported HIF- $1 \alpha$ in improving mitochondrial function, reducing cellular oxidative stress, and stimulating the cardioprotection [39].

Furthermore, HIF- $1 \alpha$ improves mitochondrial respiratory function by triggering various cardioprotective signaling pathways, including the phosphoinositide-3-kinase/Akt (PI3K/AKT) and Janus kinase (JAK) 2/signal transducer and activator of transcription (STAT) 3, to protect the heart during I/R injury [50]. Indeed, Nanayakkara and colleagues reported the transcriptional role of HIF- $1 \alpha$ during hypoxia in regulating frataxin expression levels, a highly conserved nuclear-encoded mitochondrial protein, expressed in tissues such as the heart, neurons, and liver with a high metabolic rate [51], which served as a cardioprotective element against ischemic injury. Ultimately, enhanced frataxin levels can alleviate mitochondrial iron overload, thereby preserving mitochondrial membrane integrity and the cardiomyocyte's viability [52]. HIF- $1 \alpha$ stabilization permits cells and tissues 
to adapt to the hypoxic response in I/R, thus protecting cardiomyocytes against IHD and improving patient prognosis [20]. On the other hand, several lines of evidence outlined the impact of HIF- $1 \alpha$ localization dependent on the mitochondrial function regulation, which has been thought to be contingent on its trafficking to the nucleus. Nevertheless, studies documented that HIF- $1 \alpha$ not only localizes to the nucleus after exposure to hypoxia or preconditioning but surprisingly it localizes also to the mitochondria [53,54]. For instance, Mylonis and collaborators reported that HIF- $1 \alpha$ at the outer mitochondrial membrane (OMM) attenuates hypoxia-induced apoptosis [55]. In alignment with this regard, during the elevation of oxidative stress, HIF- $1 \alpha$ translocates to the mitochondria to reduce mitochondrial reactive oxygen species (mtROS) in the human umbilical vein endothelial (HUVEC) during hypoxia [56].

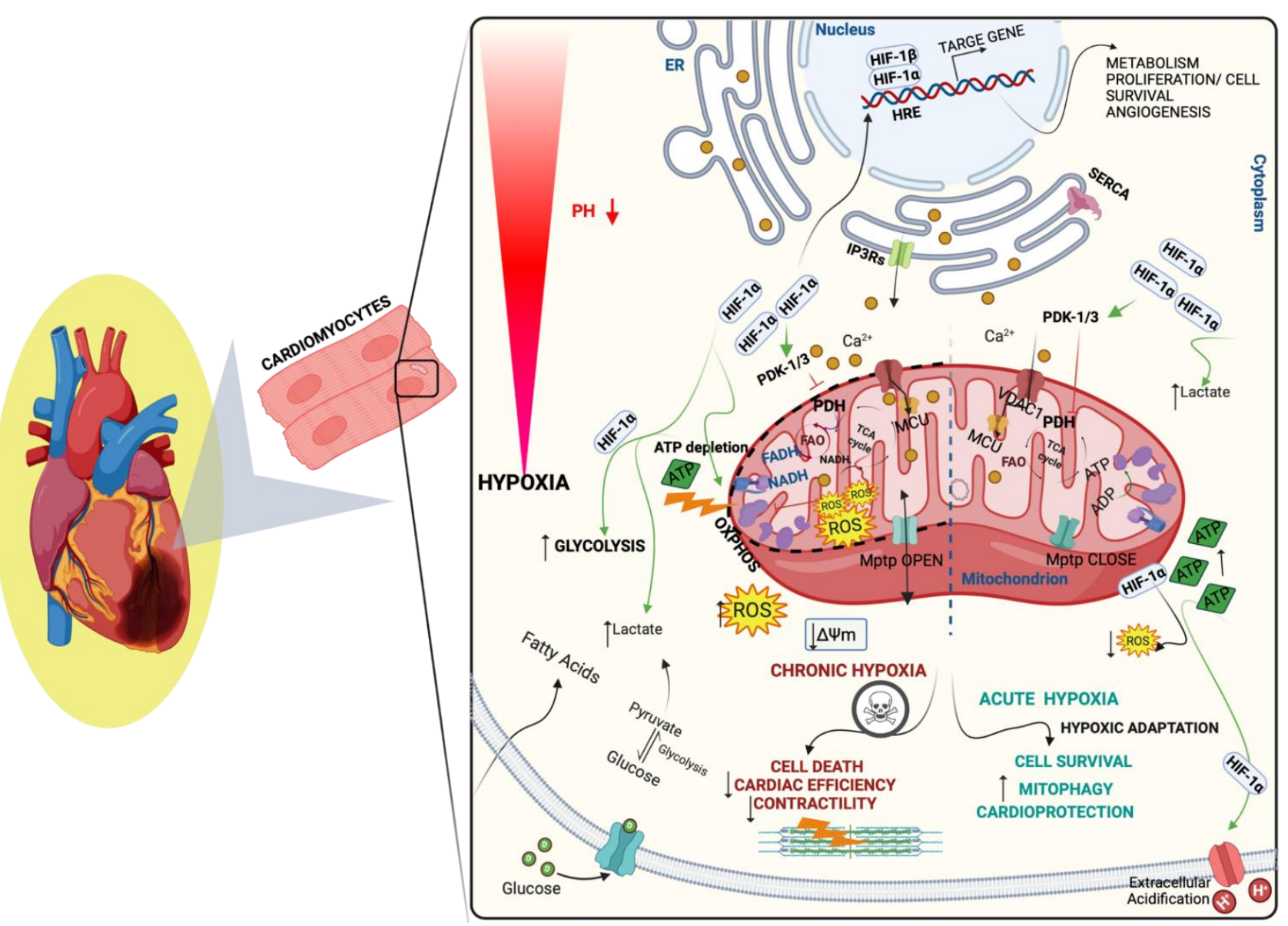

Figure 2. Hypoxic-inducible factor- $1 \alpha(\mathrm{HIF}-1 \alpha)$ signaling and mitochondria in cardiovascular diseases (CVDs). Sudden decrease in oxygen $\left(\mathrm{O}_{2}\right)$ levels results in abrupt biochemical and metabolic changes. Hypoxia causes the accumulation of HIF- $1 \alpha$ that moves to the nucleus to activate genes crucial to a metabolic switch away from the mitochondrial oxidative phosphorylation system (OXPHOS) to glycolysis, the cardiomyocyte relies on anaerobic respiration instead of oxidative phosphorylation, which in turn causes disruption of the mitochondrial membrane potential $\left(\Delta \Psi_{\mathrm{m}}\right)$ and adenosine triphosphate (ATP) depletion, affecting the mitochondrial Permeability Transition Pore (mPTP) opening and subsequently inhibiting contractile function. Hypoxia triggers a switch in cellular metabolism to anaerobic glycolysis, causing acidification of the cell as protons $\left(\mathrm{H}^{+}\right)$accumulates. Cardiomyocyte damage and mitochondrial deficiency are relatively linked to the degree of hypoxia exposure and due to the dual effect of HIF- $1 \alpha$; in acute hypoxia (right), HIF- $1 \alpha$ acts as cardioprotective against oxidative damage by alleviating ROS generation and stimulating the removal of unwanted mitochondria through mitophagy. While (left) HIF-1 $\alpha$ enhances ROS levels and increases cell death, ultimately, reduces cardiac efficiency and contractility. 
Table 1. Representative list summarizing the effect of HIF- $1 \alpha$ in cardiovascular diseases. HIF- $1 \alpha^{t g}$ mice: HIF- $1 \alpha^{t g}$ transgenic mice models. $\mathrm{CH}$ rodent models: chronic hypoxic rodent models. LPS: lipopolysaccharide.

\begin{tabular}{|c|c|c|c|c|c|}
\hline $\begin{array}{l}\text { Cardiovascular } \\
\text { Disorders }\end{array}$ & In Vivo/In Vitro & Animal Models & Cell Lines & HIF-1 $\alpha$ Effect & References \\
\hline \multirow{3}{*}{$\begin{array}{l}\text { Ischemia-reperfusion } \\
\text { injury (I/R injury) }\end{array}$} & In vitro & - & $\begin{array}{c}\text { Rat neonatal } \\
\text { ventricular } \\
\text { cardiomyocytes } \\
\text { cells }\end{array}$ & $\begin{array}{c}\text { Cardioprotective effect, } \\
\text { overexpression of HIF-1 } \alpha \\
\text { elevated target genes (iNOS, } \\
\text { VEGF, HSP70, and GLUT1-4) }\end{array}$ & [32] \\
\hline & In Vivo/in vitro & $\mathrm{PHD}^{-/-}$mice & $\begin{array}{c}\text { HL-1 } \\
\text { cardiomyocytes }\end{array}$ & $\begin{array}{l}\text { Cardioprotection, } \\
\text { PHD3 deletion increased HIF-1 } \alpha, \\
\text { resulted in cardiomyocytes death } \\
\text { suppression }\end{array}$ & {$[30,31]$} \\
\hline & In Vivo/in vitro & $\begin{array}{l}\text { Sprague Dawley } \\
\text { (SD)/rat model }\end{array}$ & $\begin{array}{c}\mathrm{H} 9 \mathrm{C} 2 \\
\text { cardiomyoblasts }\end{array}$ & $\begin{array}{c}\text { Cardioprotection, } \\
\text { BNIP3-mediated autophagy } \\
\text { modulation }\end{array}$ & [39] \\
\hline \multirow[b]{2}{*}{$\begin{array}{l}\text { Myocardial infraction } \\
\text { (MI) }\end{array}$} & In Vivo & Post-MI mice & - & $\begin{array}{l}\text { Cardioprotection, } \\
\text { upregulated angiogenesis }\end{array}$ & [57] \\
\hline & In vivo/in vitro & MI-mice & $\begin{array}{l}\text { Rat neonatal } \\
\text { cardiomyocytes }\end{array}$ & $\begin{array}{l}\text { Detrimental, } \\
\text { stimulated apoptosis through p53 } \\
\text { following MI }\end{array}$ & [58] \\
\hline Heart failure (HF) & In vivo & HIF- $1 \alpha^{t g}$ mice & - & $\begin{array}{c}\text { Detrimental, } \\
\text { prolonged HIF-1 } \alpha \text { accumulation } \\
\text { increased disease development }\end{array}$ & [28] \\
\hline Myocarditis & In vitro & - & $\begin{array}{c}\mathrm{H} 9 \mathrm{C} 2 \\
\text { cardiomyoblasts }\end{array}$ & $\begin{array}{l}\text { Detrimental, } \\
\text { repression of HIF-1 } \alpha \text { improved } \\
\text { cardiomyocytes at odds with } \\
\text { LPS-stimulated cell death }\end{array}$ & [29] \\
\hline $\begin{array}{c}\text { Dilated } \\
\text { cardiomyopathy }\end{array}$ & In vivo & $\mathrm{PHD}^{-/-}$mice & - & $\begin{array}{c}\text { Detrimental, } \\
\text { prolonged HIF- } 1 \alpha \text { upregulation } \\
\text { promoted dilated } \\
\text { cardiomyopathy }\end{array}$ & [38] \\
\hline $\begin{array}{l}\text { Cyanotic congenital } \\
\text { heart disease (CCHD) }\end{array}$ & In Vivo & $\mathrm{CH}$ rodent models & - & $\begin{array}{c}\text { Cardioprotection, } \\
\text { HIF-1 } \alpha \text { overexpression alleviated } \\
\text { maladapted metabolic }\end{array}$ & [59] \\
\hline Cardiac hypertrophy & In Vivo & HIF- $1 \alpha$ KO mice & - & $\begin{array}{c}\text { Cardioprotection by controlling } \\
\text { negatively TGF- } \beta\end{array}$ & [60] \\
\hline
\end{tabular}

\subsection{Hypoxia Signaling and Mitochondria in Cancer}

Multicellular organisms have adopted several mechanisms to rapidly adjust to hypoxia, prolonging survival in the absence of adequate resource [61]. A common observation of most tumors is an insufficient amount of $\mathrm{O}_{2}$, the severity of which varies between tumor types. In proliferating and expanding tumor tissue, the adaptation of tumor cells to exhausted oxygen supply is mainly mediated by HIF-1. Such metabolic adjustment is pivotal for cancer cell survival and proliferation in response to environmental stimuli [62].

In this section, we will discuss how hypoxia affects the mitochondrial function through TCA citric acid cycle, electron transport chain, and its dual role of hypoxia in ROS production and mitigation and finally briefly consider hypoxia-induced mitochondrial distribution and morphology in cancer.

\subsubsection{Hypoxia-Induced Modulation of Krebs Cycle and Oxidative Respiration}

TCA cycle represents the metabolic engine within cells. It is found to be inhibited by HIF- $1 \alpha$ through the induction of the enzyme PDK1. PDK1 inactivates the TCA cycle enzymes by phosphorylating PDH, which converts pyruvate to acetyl-CoA. PDK1 overexpression in HIF- $1 \alpha$-silenced cells led to an increased ATP production, reduced ROS generation and prevented the hypoxia-mediated apoptosis [9]. Indeed, the accumulation of 2-hydroxyglutarate (2-HG), an essential epigenetic regulator in cancer cells, has been 
documented to enhance the stabilization of HIF-1 $\alpha$ [63]. Importantly, HIF-1 $\alpha$ was found to act as a metabolic switch from glycolysis to OXPHOS for regulatory T cells glioblastoma. Specific ablation of HIF- $1 \alpha$ in regulatory T cells resulted in enhanced pyruvate import into mitochondria [64]. Taken together, TCA cycle metabolites resulted to be affected by hypoxia to limit substrate availability for phosphorylation and epigenetic modifications to change cell function and fate.

In addition, the effect of HIF- $1 \alpha$-mediated metabolic reprograming also alters OXPHOS respiration [65]. Evidently, MCF-7 carcinomas cells exposed to 24h hypoxia showed reduced OXPHOS flux and decrease 2-OG dehydrogenase as well as glutaminase activities, without functional alteration of respiratory complexes I and IV [66] (Table 2). Other possible ways by which hypoxic cells reduce oxidative metabolism involve small RNAs. HIFs increased transcription of genes encoding microRNAs (miRs), small RNAs that link to mRNAs in sequential mode to either suppress their translation or promote their degeneration. Among the list of targets of miR-210, there are the iron-sulfur cluster enzyme (ISCU) genes, required for mitochondrial complex I function, which are particularly found downregulated under hypoxia [67]. Moreover, a bioinformatics survey and PCR real-time experiments demonstrated the involvement of both nuclear respiratory factors (NRF-1) and HIF- $1 \alpha$ in modulating voltage-dependent anion-selective channel 1 (VDAC1) promoter during nutrients deprivation or hypoxia [68]. Taken together, cancer cells activate a metabolic switch that involve HIF- $1 \alpha$ and impaired Krebs cycle and OXPHOS function to sustain glycolysis metabolism.

Table 2. Representative list summarizing the effect of HIF- $1 \alpha$ on mitochondria in cancer.

\begin{tabular}{|c|c|c|c|c|c|}
\hline Cancer Disorders & In Vivo/In Vitro & Animal Models & Cell Lines & HIF-1 $\alpha$ Effect & References \\
\hline $\begin{array}{l}\text { Human Breast ductal } \\
\text { carcinoma }\end{array}$ & In vitro & - & MCF-7 cells & $\begin{array}{l}\text { Inhibited ER Estrogen receptor } \\
\text { expression }\end{array}$ & [62] \\
\hline Renal carcinoma & In vitro & - & RCC4 and RCC10 & $\begin{array}{l}\text { Increased mitochondrial } \\
\text { biogenesis }\end{array}$ & [69] \\
\hline $\begin{array}{l}\text { Hepatocellular } \\
\text { carcinoma (HCC) }\end{array}$ & In vivo & $\begin{array}{l}\text { Mice and Diethylni- } \\
\text { trosamine model of } \\
\text { Murine HCC }\end{array}$ & HCC cell lines & $\begin{array}{l}\text { Promoted mitochondrial } \\
\text { biogenesis and reduced ATP }\end{array}$ & [70] \\
\hline \multirow{3}{*}{$\begin{array}{l}\text { Triple negative breast } \\
\text { cancer (TNBC) }\end{array}$} & In vitro/in vivo & Nude mice & MDA-MB-231 & $\begin{array}{l}\text { Enhanced mitochondrial } \\
\text { OXPHOS and elevated ROS } \\
\text { generation }\end{array}$ & [71] \\
\hline & In vitro & - & $\begin{array}{l}\text { MDA-MB-231 } \\
\text { and SUM-149 cells }\end{array}$ & $\begin{array}{l}\text { Increased intracellular } \\
\text { glutathione levels }\end{array}$ & [72] \\
\hline & In vivo & MMTV-PyMT mice & Primary MECs & Regulated mitochondrial mass & {$[73,74]$} \\
\hline Colorectal cancer & In vitro/in vivo & Oma1 $^{-/-}$mice & HCT116 cells & Increased mitochondrial ROS & [75] \\
\hline Several human cancers & In vitro & - & $\begin{array}{c}\text { A549, CCL39, } \\
\text { HeLa, LS174, } \\
\text { MCF7, PC3, ORL33, } \\
\text { SKMel, and 786-O } \\
\text { cells }\end{array}$ & $\begin{array}{l}\text { Enlarged mitochondrial } \\
\text { phenotype }\end{array}$ & [76] \\
\hline Glioblastoma & In vitro/in vivo & $\begin{array}{l}\text { Foxp3-YFP-CRE } \times \\
\text { HIF-1 } \alpha \text {-flflf mice }\end{array}$ & $\begin{array}{l}\text { Murine glioma } \\
\text { GL-261 }\end{array}$ & $\begin{array}{l}\text { Promoted fatty acids oxidation for } \\
\text { mitochondrial metabolism }\end{array}$ & [64] \\
\hline Cancer cachexia (CC) & In Vitro/in vivo & C26 mice model & $\begin{array}{l}\text { Colon-26 (C26) } \\
\text { adenocarcinoma }\end{array}$ & Affected the metabolic changes & [77] \\
\hline Oral cancer & In vitro & - & $\begin{array}{l}\text { Oral squamous cell } \\
\text { carcinoma (OSCC) }\end{array}$ & $\begin{array}{l}\text { Stimulated migration and } \\
\text { invasion in the indicated cells }\end{array}$ & [78] \\
\hline
\end{tabular}

\subsubsection{Hypoxia-Induced Mitochondrial ROS Production and Suppression}

ROS are actively generated in the form of superoxide and hydroxyl free radicals as a by-product of OXPHOS and neutralized by antioxidant mechanism to ensure a proper cellular function [79]. Indeed, in breast cancer cell line (MDA-MB-231), the inhibition of HIF$1 \alpha$ expression using cardamonin repressed the mechanistic target of rapamycin (MTOR) 
pathway causing increased OXPHOS activity and enhanced ROS, which finally led to apoptosis [71]. Similarly, colorectal cancer cells under hypoxic conditions are characterized by activation of OMA1-OPA1 axis, which in turn increase the mtROS generation to stabilize HIF- $1 \alpha$, thereby promoting the glycolytic metabolism [75]. There is also evidence that mitigating ROS-mediated damage in hypoxia may promote the Warburg effect, an altered metabolism favoring enhanced uptake and use of glucose. Warburg effect has been also involved during the pathogenesis of cancer cachexia (CC), which is a complex pathological condition with metabolism dysregulation, affecting primarily the skeletal muscle [80]. The impaired mitochondrial homeostasis and metabolism has also been documented in various models of CC. Additionally, it has been suggested that HIF-1 $\alpha$ may have an impact on the metabolic alteration in cancer cachexia (CC) [77]. Consistently, suppressing HIF- $1 \alpha$ expression by Rhein and Emodin compounds mitigates cancer cell proliferation and CC in a dose- and time-dependent mode [81,82].

This indicates that the alleviation of ROS may promote the antioxidant system. Particularly, stimulation of AMP-activated protein kinase (AMPK) by mitochondrial ROS led to peroxisome proliferator-activated receptor gamma coactivator 1-alpha (PGC-1 $\alpha$ )dependent antioxidant response. Mechanically, AMPK-PGC- $1 \alpha$ induced regulation of mitochondrial ROS mediates the HIF- $1 \alpha$ stabilization [83]. Interestingly, opposite to earlier experimental observations, downregulation of superoxide dismutases (SOD2) expression has also been observed under hypoxia in a HIF-1 dependent manner in renal carcinoma cells [84]. Similarly, HIF-1 increased glutathione levels by upregulating glutamate cysteine ligase (GCLM) in breast cancer cells (MDA-MB-231 and SUM-149 cells) [72].

\subsubsection{Hypoxia-Induced Mitochondrial Distribution and Dynamics}

The mitochondrial distribution and dynamics are permitted by a correct balance between two opposite processes, that are the mitochondrial biogenesis and the mitochondrial fission. In addition to this, mitochondria removal mechanisms which permit the elimination of damaged and excessed mitochondria guarantees the preservation of a healthy mitochondrial pool. Among the diverse mechanisms regulating this mitochondrial turnover, the selective form of autophagy pathway, known as mitophagy [85], represents the primary line of intervention. Dysfunctions in such mitochondrial-related pathways may be cause and consequence of several disorders [86-89] and can be also related to a hypoxic condition. For example, it has been observed that cancer cells activate mitochondrial fusion to enlarge their mitochondrial population to evade from cell death stimuli. Consistently, inhibition of the mitochondrial fusion protein mitofusin-1 (MFN-1) reestablish a tubular network [76]. Other factors appear to influence the hypoxia-mediated fission of mitochondrial membranes. This is the case of the mitochondrial scaffolding protein A-kinase anchor protein 1 (AKAP121). During hypoxia, AKAP121 regulates mitochondrial dynamics through inhibition of phosphorylation of the main regulators of mitochondrial fusion events: the dynamin-related protein 1 (DRP1) and the fission 1 protein (FIS1). Interestingly, this work also accounted for the ubiquitin ligase SIAH2 a crucial role in regulation of hypoxia-mediated mitochondrial fission. Indeed, it is well documented that AKAP121 is a SIAH2 substrate and, of consequence, the availability of AKAP121 as well as the associated mitochondrial dynamics under hypoxia are highly dependent of SIAH2. Consistently, SIAH2 knockout (KO) cells displayed higher AKAP121 levels [90]. In addition, the mitochondrial biogenesis has important roles in cancer cells to adapt hypoxia. Microarray studies show that reconstitution of pVHL in renal carcinoma led to elevated mitochondrial mass, mitochondrial complexes activity and $\mathrm{O}_{2}$ consumption rates. Mechanistic insights show MAX-interactor 1 (MXI1) expression reduces C-MYC-dependent expression of PGC- $1 \alpha$, which in turn inactivate mitochondrial biogenesis [69]. Similarly, ablation of high mobility group box 1 (HMGB1) protein in hepatocellular carcinoma subjected to hypoxia promoted mitochondrial biogenesis and reduced ATP. Mechanistic experiments suggest that the binding of HMGB1 to Toll-like receptor-9 in cytoplasm stimulate p38 which in turn led to phosphorylation of PGC-1 $\alpha$, which resulted in subsequent increase mitochondrial biogenesis [70]. There are 
several reasons given why tumor hypoxia maintain increased mitochondrial biogenesis. Thanks to this condition cancer cells result protected from cell damage induced by ROS, thereby providing a survival mechanism. Another benefit is to enhance their migratory and invasive properties to other zones with less hypoxia [91].

As reported above, central to keeping healthy mitochondrial population and guarantee and efficient turnover of the mitochondrial population is mitophagy [92]. The exact role of mitophagy in cancer remains unresolved, as it has divergent roles, either blocking or stimulating the cancer progression [93]. Interestingly, growing consensus documented an intimate relationship between mitophagy and hypoxia in regulate the tumor growth. Indeed, the mitophagy proteins BNIP3L/NIX, BNIP3, and FUNDC1 were found upregulated in response to hypoxia in cancer [94-96]. Furthermore, BNIP3 and NIX are target genes of HIF- $1 \alpha$ and their upregulation stimulates mitophagy under hypoxia and inhibits cancer progression in MMTV-PyMT model under hypoxia through activated HIF [73,74]. In addition to this, the protein E2F3d, recently stated to localize to the OMM, revealed to augment the process of mitophagy during hypoxic exposure in cancer cells [97].

During hypoxia, HIF- $1 \alpha$ regulates glucose, glutamine metabolisms, and lipid through various target genes, by which it enhances glycolysis by upregulating glucose transporters to induce the glycolysis flux and targeting PDK-1/3 to inhibit pyruvate changeover to acetyl $\mathrm{CoA}$ and stimulating LDH-A to turn the pyruvate to lactate. HIF- $1 \alpha$ upregulates glutamine utilization and activates fatty acids for rapid cell growth and division. Moreover, when $\mathrm{O}_{2}$ supply is limited, tumor cells are protected against excessive ROS and subsequently they resist to cell death.

\section{Mitochondrial Dysfunction and Inflammation in CVDs and Cancer}

\subsection{Oxidative Stress and Mitochondria}

Under physiologic conditions, other organelles in addition to mitochondria have the capacity to produce ROS such as peroxisome and endoplasmic reticulum (ER) [98]. Despite this, several lines of evidence ascribe to mtROS a predominant role in CVDs as well as in cancer (as reviewed in [99-101]). In the mitochondrion, ROS are produced by ETC in the IMM at the level of complex I and III during oxidative metabolism and cellular response to cytokines and bacterial invasion. Moreover, several enzymes here located or translocated following stimuli are considered additional sources of mtROS [102], and they include several flavoproteins (acyl-CoA dehydrogenase, glycerol $\alpha$-phosphate dehydrogenase, $\alpha$-ketoglutarate dehydrogenase) [103-105], the monoamine oxidases (MAOs) on OMM that produces ROS in the catabolism of neurotransmitters [106], aconitase [107], the ROSgenerating NADPH oxidases (NOXs) [108], and p66shc in the intermembrane space (IMS) which oxidizes cytochrome c $[109,110]$. All these enzymes share the release of discrete amounts of superoxide $\left(\mathrm{O}_{2}{ }^{-}\right)$and hydrogen peroxide $\left(\mathrm{H}_{2} \mathrm{O}_{2}\right)$ which have been linked to a consequent mitochondrial swelling and apoptosis [109]. Moreover, the $\mathrm{O}_{2}{ }^{-}$produced in these steps is able to react also with nitric oxide (NO) giving rise to reactive nitrogen species (RNS) production and consequent nitrosative stress, which involves mitochondria because affects their enzymatic activity, modifies mitochondrial respiration and increases mitochondria-mediated cell death [111].

Uncontrolled ROS and RNS production, generate oxidative stress with consequent mtDNA damage and oxidation of proteins and lipids of membranes. In the first case, ROS and RNS directly react with pyrimidine and purine bases, especially in the D-loop region [112]; here, this damage led to a significant decrease in mtDNA copies and of ETC function [113]. Otherwise, peroxidation of mitochondrial lipids and proteins alters the mitochondrial membrane potential (MMP), their energy production and triggers the opening of MPTP $[105,109,110]$. Subsequently, mitochondria result impaired, and several cell death pathways are activated.

$\mathrm{mtROS}$ scavenging systems exist and they represent the first line of defense against toxic ROS levels. Superoxide dismutase (SOD) is responsible for the conversion of $\mathrm{O}_{2}$ - in $\mathrm{H}_{2} \mathrm{O}_{2}$. SOD exists in three isoforms and, among them, SOD2 has a mitochondrial matrix 
localization, while SOD1 (Cu/Zn SOD) may be partially found in the intermembrane space. A second line of defense is covered by catalase, which splits in $\mathrm{O}_{2}$ and water [114]. The action of this enzyme is flanked by the glutathione peroxidase/reductase (GSH-PX) and the peroxiredoxin/thioredoxin (PRX/Trx) systems which taking advantage from the reduced forms of GSH and PRX, they convert $\mathrm{H}_{2} \mathrm{O}_{2}$ in water. PRX3 and PRX5, as well as Trx2 are localized to mitochondria.

\subsection{Inflammation and Mitochondria}

It is currently recognized that ROS induces inflammation $[115,116]$ and, in turn, inflammation further sustains mitochondrial dysfunction [117]. Mitochondria are organelles involved in the inflammatory process not only to produce ROS, but because in particular conditions (i.e., the opening of the MPTP or the permeabilization of the OMM) [118,119], they release into the cytosol several factors named as DAMPs (danger-associated molecular patterns). To date, many substances are recognized as mtDAMPs, and they include mtDNA [120], ATP [121], TFAM [122], NFP [123], succinate [124], and cardiolipin [125]. These molecules, once in the cytosol and sometimes in the extracellular milieu, are recognized by other molecules (adaptors or receptors) to trigger inflammation. There are different pools of receptors. Those recognizing mtDAMPs, which link mitochondria to inflammation, are the cytoplasmic nucleotide-binding domain leucine-rich repeat-containing receptors (NLRs). The most common and well-defined is the NLR and pyrin containing protein 3 (NLRP3). It exists as a multiprotein complex composed of the scaffold protein NLRP3. Normally localized in the cytosol, NLRP3 moves to the mitochondria and MAMs upon activation, and it regulates the innate immunity by recruiting the apoptosisassociated speck-like protein (ASC; an adaptor) and procaspase-1, which becomes matured in caspase- 1 and is responsible for the activation of IL-1 $\beta$ and IL-18 [115]. The contribution of mitochondria in NLRP3-mediated inflammation is demonstrated by their recruitment in the cytoplasm of macrophages in a process mediated by microtubules [126] and the observation of NLRP3 relocalization to mitochondria following stressors. Indeed, under resting conditions, NLRP3 is normally localized at the ER, but after stimulation with mtDAMPs, NLRP3 clusters at mitochondria and at MAMs [124]. Thus, inflammation and mitochondria are directly related and together with ROS contribute to both CVDs and cancer.

\subsection{Inflammation, Oxidative Stress, and Mitochondrial Dysfunction following Hypoxia in CVDs}

Inflammation and oxidative-nitrosative stress are two main contributing causes in the onset and progression of CVDs [127]. In addition being crucial in the excitation-contraction coupling of the heart [128], mitochondria are at the crossroad between both routes, as these are often accompanied by an alteration of mitochondrial function. Inflammation has a key role in CVDs, as an example, atherosclerosis, plaque and vessel calcification, and post-ischemic pathologies. Atherosclerosis born from cholesterol, fat, and other substances deposition on the inner side of vessels. These deposits build up into the vessel in concomitance of endothelial dysfunction, the starting artery lesion, to lead to the plaque formation. Direct evidence of the regulation of lipid metabolism by hypoxia and HIF-a still lack in CVDs. However, it has been suggested that hypoxia-induced HIF-1 $\alpha$ accumulation upregulates the expression of its target genes and affects the lipid metabolism of hypoxic macrophages in atherosclerosis, thereby providing evidence of a possible atherogenic role for hypoxia [129]. Lipids can be also modified by further oxidation from newly generated mtROS, and adhesion molecules (ICAM and VCAM) are activated to trigger the binding of inflammatory cells, such as monocytes. Often, cholesterol deposition represents the second hit in NLRP3 assembly for the production of interleukins and inflammation progress [130]. Inflammation is also responsible for the calcification of the plaque; indeed, activated macrophages promote the apoptosis of interstitial cells by releasing proinflammatory cytokines and promoting the release of vesicles reached in calcium $\left(\mathrm{Ca}^{2+}\right)$ and phosphates [131,132]. Similarly, an increase of aged mitochondria, reduced biogenesis, 
impaired mitophagy, and dysregulated cytosolic $\mathrm{Ca}^{2+}$ homeostasis are all associated with mitochondrial dysfunction $[76,129,130]$.

On the other hand, mitochondrial oxidative stress has been found closely related to several risk factors for CVDs, and from studies in vitro and in vivo it has been found to be one of the main mediators of apoptosis in cardiomyocytes and endothelial dysfunctions [101,133]. The contribution of each of the above-mentioned ROS-producing enzymes in CVDs has been analyzed overtime in experimental settings including genetic manipulation of animal models. As an example, p66SHC is considered an important modulator of mitochondria-mediated cell death as it regulates MMP and ROS when localized to the mitochondria [134]. Accordingly, animals lacking p66SHC display reduced ROS and decreased cell death in a model of hypertension and HF [135]. Elevated levels of angiotensin II upregulate redox-sensitive pathways causing mtROS overproduction, cardiomyocyte damage, and finally hypertension and HF. The $\mathrm{p} 66 \mathrm{SHC}^{-/-}$phenotype benefits in cardiac function are not only against the previously mentioned pathologies but also in a model of diabetic cardiomyopathy [136]. Likewise, the inhibition or deletion of isoform A of MAOs in murine models decreases mtROS production, preserves the heart against pressure overload, caspase 3 activation, and fetal gene reprogramming [137]. In addition, MAO-B targeting in a mouse model of induced pressure overload minimizes the worsening of the cardiac function and reduces death by preserving MMP and mitochondrial bioenergetics [138]. NOX isoforms, NOX4, constitute the main source of oxidative stress during HF [139]. In support of this, its levels are significantly elevated following chronic pressure overload. Consequently, oxidative stress, mitochondrial dysfunctions, and apoptosis are activated. Mice lacking NOX4 have lower left ventricular (LV) dysfunction with reduced oxidative stress and cardiomyocyte apoptosis [140].

The dysregulation of the antioxidant systems is the second aspect that demonstrates how mitochondrial oxidative stress is deleterious in heart disease. Studies from SOD2 ${ }^{-/-}$ mouse model reported either premature lethality [141] or deaths before 4 months due to HF. Indeed, the absence of this enzyme triggers excessive oxidative stress in mitochondria with the overproduction of 4-hydroxynonenal (4-HNE), produced from lipid peroxidation and a player in mitochondrial dysfunction, by acting via the severe impairment of the ETC [142].

The deriving phenotype consists of abnormalities in mitochondrial structure, decreased ejection fraction, dilated, and dysfunctional LV, all major phenotypes of dilated cardiomyopathy [142]. Deleterious effects are not limited to the complete deletion of SOD2. In a study in humans, the single Ala16Val SOD2 polymorphism has been investigated as associated with coronary heart disease (CHD) risk, in concomitance with decreased SOD2 activity and increased mtROS production [143]. In addition, endothelial dysfunction is increased when SOD2 is absent [144]. In the end, the inappropriate activity of GSH-PX and PRX/Trx systems enhance oxidative stress, which is the main cause of left ventricle (LV) contractile dysfunction and abnormalities in LV mass, under the action of angiotensin II [145]. If we consider these genotypes following I/R, they produce larger infarct size, alteration of cardiac contractility, cell death, and adverse events such as HF and dilated cardiomyopathies [146,147].

Overall, in understanding the importance of all these compensatory mechanisms in humans, an extensive meta-analysis on thousands of papers published and as many patients analyzed, reported an inverse and significant correlation between antioxidant systems activity (and circulating levels of enzymes involved in) and the most common risk factors of CHD [148].

Hypoxia is a bio-clinical condition in which either portion or whole tissues are subjected to a significant imbalance between $\mathrm{O}_{2}$ consumption and blood perfusion [149]. It is often associated with nutrient deprivation. In normal conditions, the cardiovascular system is appointed to guarantee these functions in the human body. However, coronary artery disease (CAD) (i.e., atherosclerosis) can arise with aging and become responsible for a progressively decrease in the blood perfusion. As a consequence, CAD may result in ischemic heart disease (IHD), such as myocardial infarction (MI) and peripheral arterial 
diseases (PAD), in which hypoxia plays a predominant role. In addition, being that hypoxia is a condition that induces changes in the cardiovascular system, its chronic presence can also lead to hypertension and HF [150]. Thus, within certain limits and with different degrees, all CVDs mentioned in the previous paragraphs are linked to hypoxia. In normoxia, HIF- $1 \alpha$ binds the pVHL for degradation by the proteosome; under hypoxic states, HIF- $1 \alpha$ accumulates and translocates mainly to the nucleus where it dimerizes with beta subunit. Being a transcription factor, in the nucleus it triggers the expression of several genes involved in either adaptation or maladaptation to hypoxia [151]. In this context, whether cells and tissues find a means to adapt in the absence of $\mathrm{O}_{2}$ levels, the reperfusion phase (if any) emphasizes the hypoxia-induced damages even more. Examples of adaptations induced by hypoxia are the HIF- $1 \alpha$ and VEGF-mediated angiogenesis in post-MI hearts to ensure a compensated $\mathrm{O}_{2}$ delivery in the infarcted tissue [57], and the downregulation of mitochondrial $\mathrm{O}_{2}$ consumption through the activity of the PDK1, which is the enzyme that limits the use of pyruvate at mitochondrial level [48]. Here, the $\mathrm{O}_{2}$ available for mitochondria increases and consequently cell death is reduced. Again, HIF- $1 \alpha$ overexpression is important for mitochondrial metabolic adaptation to a persistent state of hypoxia in the heart, which distinguishes patients with cyanotic congenital heart disease (CCHD) [152]. Moreover, HIF- $1 \alpha \mathrm{KO}$ mice in which pressure overload is induced, immediately present severe traits of hypertrophy when compared to their wildtype littermates [60]. Note that it is no coincidence if hypoxic conditioning is considered as a non-pharmacological therapeutic intervention in the adaptation of the body against severe $\mathrm{O}_{2}$ deprivation episodes [153]. However, chronic or sustained hypoxia states and all associated prosurvival pathways are better associated to cancer. In full-blown IHD, mechanical methods and pharmacological treatments are usually suddenly applied to solve the ischemic phase, also known as the cause of the necrotic core of the lesion. One of them is the reperfusion of the occluded vessels.

Mitochondria are the major consumers of $\mathrm{O}_{2}$, and as consequence, they suffer from its absence. Whether in the normoxic condition the cell respire in the aerobic mode and produce big amount of ATP, under hypoxia ETC is inhibited in favor of glycolysis which is upregulated with consequent acidification of the environment, sodium and $\mathrm{Ca}^{2+}$ overload and breakdown of ATP production [154,155]. In the reperfusion phase, the reactivation of the ETC and the restoration of the MMP prompt further $\mathrm{Ca}^{2+}$ intake and a burst of mtROS production. These two events increase the susceptibility of mPTP to open [156]. $\mathrm{Ca}^{2+}$ enters the organelles by the mitochondrial calcium uniporter (MCU) complex, a highly selective channel in the IMM, ensuring $\mathrm{Ca}^{2+}$ uptake [157]. Indeed, cardiac-specific knockdown of MCU increases resistance against mPTP opening and reduces infarct size following ischemia $[158,159]$. On the other hand, most mtROS derive from an accurate and selective metabolic process which has been investigated by Chouchani and co-workers in 2014. By analyzing several ischemic and re-perfused tissues (i.e., brain, kidney, heart), they identified a mitochondrial metabolite that increased in concentration 19-fold during hypoxia: succinate. It accumulated proportionally to the time of the ischemic phase, and it was rapidly metabolized at reperfusion time, just when ROS increased. In this work, they supported the hypothesis that succinate comes from the reduction of fumarate by the reversal mode of succinate dehydrogenase (SDH) action. Indeed, fumarate also increases in ischemia through the activation of malate/aspartate shuttle and purine nucleotide cycle [160]. Succinate at reperfusion would produce mtROS by acting on complex III and inducing the reverse mode of complex I; in addition, it behaves like a DAMP to sustain inflammation. Thus, both $\mathrm{Ca}^{2+}$ and ROS constitute a second hit for the mPTP opening, following the ischemic priming phase. MPTP gives rise to and is accompanied by most mitochondrial dysfunctions that occur following hypoxia, including the mitochondrial permeability transition, the collapse of the MMP, and loss of cristae morphology and several proteins into the cytosol that trigger cell death and/or inflammation. In turn, mPTP opening stimulates mtROS production and all together facilitate the disassembly of super complexes of the ETC (i.e., complexes I+III+IV) further increasing ROS generation [161]. 
There is evidence of a strong upregulation of NLRP3-dependent inflammation following hypoxia both in cardiac fibroblasts and cardiomyocytes, which seems to have different but complementary roles. In cardiac fibroblasts, NLRP3 upregulation would sustain inflammation by IL $-1 \beta$ release and contribute to cardiac remodeling; in cardiomyocytes it induces pyroptosis by the solely activation of mature caspase 1 [162,163].

\subsection{Hypoxia-Mediating Signaling Pathways and Cell Death in CVDs}

Programmed cell death such as apoptosis, necrosis, and ferroptosis occur in cardiomyocytes and they are considered as central features in the pathogenesis of CVDs. In addition to the studies mentioned above on hypoxia-related oxidative stress and inflammation, several lines of evidence reported the involvement of hypoxia in mediating programmed cell death "apoptosis" in cardiomyocytes. Increased expression of HIF-1 $\alpha$ upregulated the apoptotic effect in cardiac (H9C2) and renal ischemia (HK2) [164]. Furthermore, prolonged HIF-1 $\alpha$ expression upregulates the activity of p53 tumor suppressor, and consequently, stimulates cardiomyocytes apoptosis following MI [58]. HIF-1 $\alpha$-mediated apoptosis may also have a central effect on HF. Indeed, as documented in some lines of evidence, a high level of HIF- $1 \alpha$ expression was identified in the late phase of HF $[28,165]$. Notably, the induction of apoptosis in CVDs upon the HIF-1 $\alpha$ axis is controversial, in which HIF-1 $\alpha$ exerts a dual role in the heart during hypoxic exposure. In one hand, it acts as a cardioprotective through its stimulation to several genes and pathways to adjust to hypoxia. On the other, it stimulates cardiomyocyte's damage through the activation of various cell death pathways [166]. Hypoxia-induced HIF-1 $\alpha$ accumulation blocks the apoptotic process by stimulating angiogenesis and declining fibrosis [167,168]. Along with that, another mechanism in which HIF-1 $\alpha$ prevents cardiomyocytes loss is by giving rise to iNOS and cardiotrophin-1 (CT-1) expression [169]. HIF-1 $\alpha$ exhibits a protective effect mostly during I/R injury [170] (Table 1). Similarly, during ischemic postconditioning, the increased level of HIF-1 $\alpha$ expression improves MI and reduces cardiac damage [171,172]. It is not surprising that HIF-1 $\alpha$ overexpression could alleviate apoptosis through the NFKB pathway under hypoxia in MI [173]. Consistently, other lines of evidence confirmed the cardioprotective effect of HIF-1 predomination against apoptosis via the impede of Bax [174]. Besides apoptosis, necroptosis and ferroptosis are nonapoptotic types of programmed cell death that occur in numerous disorders particularly in HF, I/R, and MI [174]. Hypoxia mediates various events including, oxidative stress, and mitochondrial deregulation thereby may stimulate cardiomyocyte necroptosis. Indeed, this process has been demonstrated to contribute to MI pathogenesis [175] and in the alteration of cardiac activity during chronic ischemia [176]. Necroptosis also has a prominent effect in cardiomyocytes loss during acute viral myocarditis, I/R injury, and atherosclerosis through its ligand death receptors including receptor-interacting protein 1, 3 (RIP1, 3) and mixed lineage kinase domain-like (MLKL) [177,178]. Recently, Karshovska and associates documented that a high level of HIF- $1 \alpha$ regulation impairs the mitochondrial bioenergetic and elevates macrophage necroptosis in the atherosclerosis [179]. Another type of regulated cell death is ferroptosis, which consists of intracellular iron dependence. Its fundamental role has been effectively stated recently in various CVDs, including cardiomyopathy, HF, MI, and myocardial I/R [59,180-182]. The iron chelator deferoxamine (DFO) is an iron chelator able to mimic hypoxia and to upregulate HIF-1 that can impede the process of ferroptosis in cardiac cells and eventually alleviates cardiac injury $[183,184]$. DFO is also able to reduce MI and to improve cardiac activity in myocardial I/R models [185,186]. Strikingly, high levels of ferroptosis have been also observed during the reperfusion stage [187]. Several other lines of evidence document the role of programmed cell death in the modulation of inflammation, which may result in cardiomyocyte ferroptosis [188]. These current findings suggest that blocking ferroptosis may prevent cardiomyocytes death. However, the processes by which hypoxia modulates cardiomyocytes death remain to be thoroughly investigated. Further specific impact of hypoxia precisely HIF-1 on ferroptosis in the heart still to be well covered. 


\subsection{Inflammation, Oxidative Stress, and Mitochondrial Dysfunction following Hypoxia in Cancer Disease}

Accumulating evidence demonstrates that inflammation is involved in all stages of tumorigenesis, including limitless replication, invasion and metastasis, apoptosis evasion, DNA damage, and angiogenesis. It remains unclear which molecular mechanism interconnects all these pathways. Recent scientific evidence suggest that the mitochondrial compartment may be the central platform for the regulation of the inflammatory response, which occurs during cancer development and growth. The ATP generated by mitochondria throughout OXPHOS is fundamental for the proliferation and differentiation of $\mathrm{T}$ cells, which are one of the main components of antitumor immunity [189]. However, different metabolic demands are required for each phenotypic stage of T cells. Indeed, upon their activation, $\mathrm{T}$ cells quickly shift to glycolysis, which guarantees a rapid energetic availability to support their growth and the production of biosynthetic factors. To boost the glycolytic pathway, the molecular axis composed of PI3K, AKT, and MTOR is the main executor. On one hand, PI3K-AKT-MTOR activates the avian myelocytomatosis virus oncogene cellular homolog (c-Myc) to increase the activity of key enzyme of glycolysis (such as the glucose transporters (GLUT)) [190] and of glutamine transporters (including glutaminase1) $[190,191]$, and on the other, the PI3K-AKT-MTOR axis works to upregulate HIF- $1 \alpha$, which, at the same time, can inhibit the TCA cycle and upregulate the expression of glycolytic enzymes. In addition to this, HIF- $1 \alpha$-induced glycolysis is fundamental to control the subpopulation of T cells. Indeed, it regulates the differentiation of Th17 [192] and of CD8+ T cells [193]. By contrast, the transition of T cells from effector to memory states mainly relies on fatty acid oxidation (FAO). Recent studies demonstrated that during this transition phase, a small amount of T cells enforces FAO by reducing the MTOR pathway and activating the AMPK pathway [194]. In addition, AMPK and FAO support the development of CD8+ T cells. Indeed, by using the AMPK activator such as metformin, the amount of memory cells as well as the lipid oxidation were increased [195]. Consistent with this, in AMPK-null T cells, the generation memory CD8 T cells upon pathogen infection was defective [196]. Interestingly, the tumor necrosis factor (TNF) receptor-associated factor 6 (TRAF6) was also important for the FAO activation in memory cells. Mice lacking TRAF6 were unable to increase FAO and displayed defects in generation of memory cells [197]. $\mathrm{T}$ cell activation and proliferation may be also promoted by ROS. However, if the ROS levels become too great, some amount of $\mathrm{T}$ cells could undergo apoptosis, thus reducing their anticancer potential. Increased ROS production may also be provoked by proinflammatory soluble molecules (such as cytokines and chemokines) that are secreted following activation of innate immune cells and by macrophages and neutrophils, which can also produce RNS. In turn, ROS and RNS provoke serious damages at the mtDNA, causing dysfunction in the production and assembly of components of the $\mathrm{METC}$, thereby enhancing the ROS production in a dangerous loop reaction. Accordingly, loss of function of mETC is frequently associated with several cancer types, such as breast cancer [198], renal cell carcinoma [199], and thyroid carcinoma [200]. Furthermore, ROS and RNS may induce mutations of genes, and relative signaling pathways, involved in both tumor activation (oncogene) and suppression (tumor suppressor). Therefore, inflammation may lead to mutagenesis. Consistently, mutations in P53, GTPase Kras (KRAS), adenomatosis polyposis coli (APC), and wingless-related integration site (WNT) have been found in intestinal cancers characterized by chronic inflammation [201]. The inflammatory environment is also responsible to drive cell survival. Inflammatory mediators released by immune cells can converge on prosurvival pathways and increase cell proliferation and resistance to cell death. In this context, IL- $1 \alpha$ and IL- $1 \beta$ promote IL-17A response, activate the NF-kB p65 subunit to cause colorectal cancer (CRC) initiation. Consistently, IL-17A was associated to poor diagnosis of CRC and inhibits the IL-1-dependent inflammation and prevented CRC development [202]. IL signaling is also responsible for promoting colitis-associated cancer. Here, IL-6 mediates cell survival and proliferation throughout the oncogenic transcription factor STAT3 [203]; alteration of the mitochondrial dynamics is an example. In fact, 
DRP1-FIS1-mediated mitochondrial fission increases the mitochondrial damage and boosts the inflammasome recruitment [204]. In addition, the hypoxic condition activates NLRP3. At demonstration, hypoxia in prostate cancer cell lines increase NLRP3 levels throughout NF-kB [205].

Furthermore, the same HIF- $1 \alpha$ can be regulated by NLRP3. In this case, it has been observed that the adaptor protein ASC associates and stabilizes HIF-1 $\alpha$ to increase cell migration and metastasis in oral squamous cell carcinoma [78]. However, other investigations demonstrate that hypoxia may be a repressor of NLRP3. Indeed, it has been demonstrated that hypoxic condition attenuates inflammation by reducing NLRP3 expression and that the isoform $\beta$ of HIF is necessary to control the expression of NLRP3 [206]. Interestingly, in this investigation, it has been demonstrated that the activation of NLRP3 required carnitine palmitoyltransferase 1A (CPT1A)-mediated enhancement of FAO [206]. Notably, CPT1A determines the entry of long-chain fatty acids into mitochondria, leading to FAO and excessive ROS production [207]. In addition, the function of NLRP3 in cancer is controversial: some evidence highlights a protective anti-tumorigenic role; others suggest pro-tumorigenic effects [208]. For example, in breast cancer, NLRP3 increases the tumor growth and metastasis by creating an inflammatory microenvironment [209,210]. In lung cancer, NLRP3 activates the prosurvival factors Akt, the extracellular signal-regulated kinase 1/(ERK1/2), and cAMP response element-binding protein (CREB) to increase cell migration, proliferation, and invasion of cancerous cells [211]. In melanoma, NLRP3 is constitutively activated [212], and its inhibition suppresses metastasis [213]. On the contrary, NLRP3 in colorectal cancer (CRC) inhibits tumor growth, senses tissue damage, and activates cell death mechanisms against the tumor cells [214,215]. In line with this, the absence of NLRP3 was correlated with the progression of hepatocellular carcinoma [216] (Figure 3). Besides, enhanced lipid peroxidation during hypoxia-mediated inflammation contributes to the stimulation of programmed cell death (apoptosis or necroptosis) in cancer cells, resulting in cellular injury and progression of multiple pathogenesis [217,218]. Notably, it has been disclosed that tumor cells have ample lipid contents [219]. As an example, in hepatocellular carcinoma (HCC), HIF-1 $\alpha$ augments lipid stabilization by alleviating FAO [220]. Lipid metabolism is abundant in tumor cells and exhibits a critical effect in tumorigenesis, invasion, and metastasis. To date, studies report the significant involvement of hypoxia in modulating various aspects of lipid metabolism, which are crucial for the enhanced proliferation rate, and subsequently, cancer progression [221]. The role of HIF-1 in lipid metabolism attracted more attention recently. Indeed, inhibiting HIF-1 or its target genes involved in lipid stabilization lead to significant alleviation of proliferation as well as chemoresistance in multiple cancer disorders in response to hypoxic circumstances [218,222-225]. By contrast, the overexpression of HIF-1-dependent lipid metabolism target genes is associated with cancer malignancy $[218,222]$.

\subsection{Hypoxia-Mediated Signaling Pathways and Cell Death in Cancer}

It is well known that most cancer cells are driven toward hypoxia-directed apoptosis. Hypoxia-induced HIF-1 $\alpha$ is stated to be associated with cancer cell malignancy and chemoradiation therapy resistance [226,227]. It is well established that HIF-1 $\alpha$ stimulates and protects cancer cells against apoptosis. For instance, high levels of HIF-1 $\alpha$ stabilization in pancreatic cells under hypoxia elicit their ability to resist against the apoptotic event compared with the normoxic cells through the HIF-1 $\alpha$-enhanced PI3K/AKT signaling pathway [228]. Although the critical role of HIF-1 in response to hypoxia-stimulated apoptosis, its molecular process in question remains unclear. Necrosis death is also involved during hypoxia in cancer. Indeed, glioma cells undergo necrosis and display resistance against prolonged hypoxia. Interestingly, this event may block the apoptotic pathway [229]. Furthermore, emerging studies have stressed the crucial role of hypoxia in ferroptosis and, given the central role of the HIF- $1 \alpha$ element upon hypoxia, its deficiency mitigates the ferroptosis sensitivity, as it modulates the transcriptional activity of genes responsible for iron metabolisms such as transferrin receptor 1 (TFR1) and Ferritin Heavy Chain 
(FTH) [230]. High levels of HIF-1 $\alpha$ protein increase the susceptibility to ferroptosis in renal carcinoma cells [231,232]. Notably, the tumor suppressor BRCA1-associated protein 1 (BAP1) is involved in apoptosis and ferroptosis in different cancer cells [233,234]. It has been demonstrated the role of BAP1 in attenuating cancer development by provoking the ferroptosis event via solute carrier family 7-member 11 (SLC7A11) inhibition [235]. Always regarding BAP1, it has been suggested that the depletion of this tumor suppressor causes enhanced HIF- $1 \alpha$ expression through the modulation of NF- $\mathrm{KB}$ in uveal melanoma [236]. Taken together, given the importance of HIF- $1 \alpha$ blockers to modulate ferroptosis in a context-dependent manner may open new directions for drug therapy [232]. Further research on the effect of hypoxia-induced HIF- $1 \alpha$ stabilization on BAP1 would shed light on new molecular mechanisms of various events including cell death in cancer.

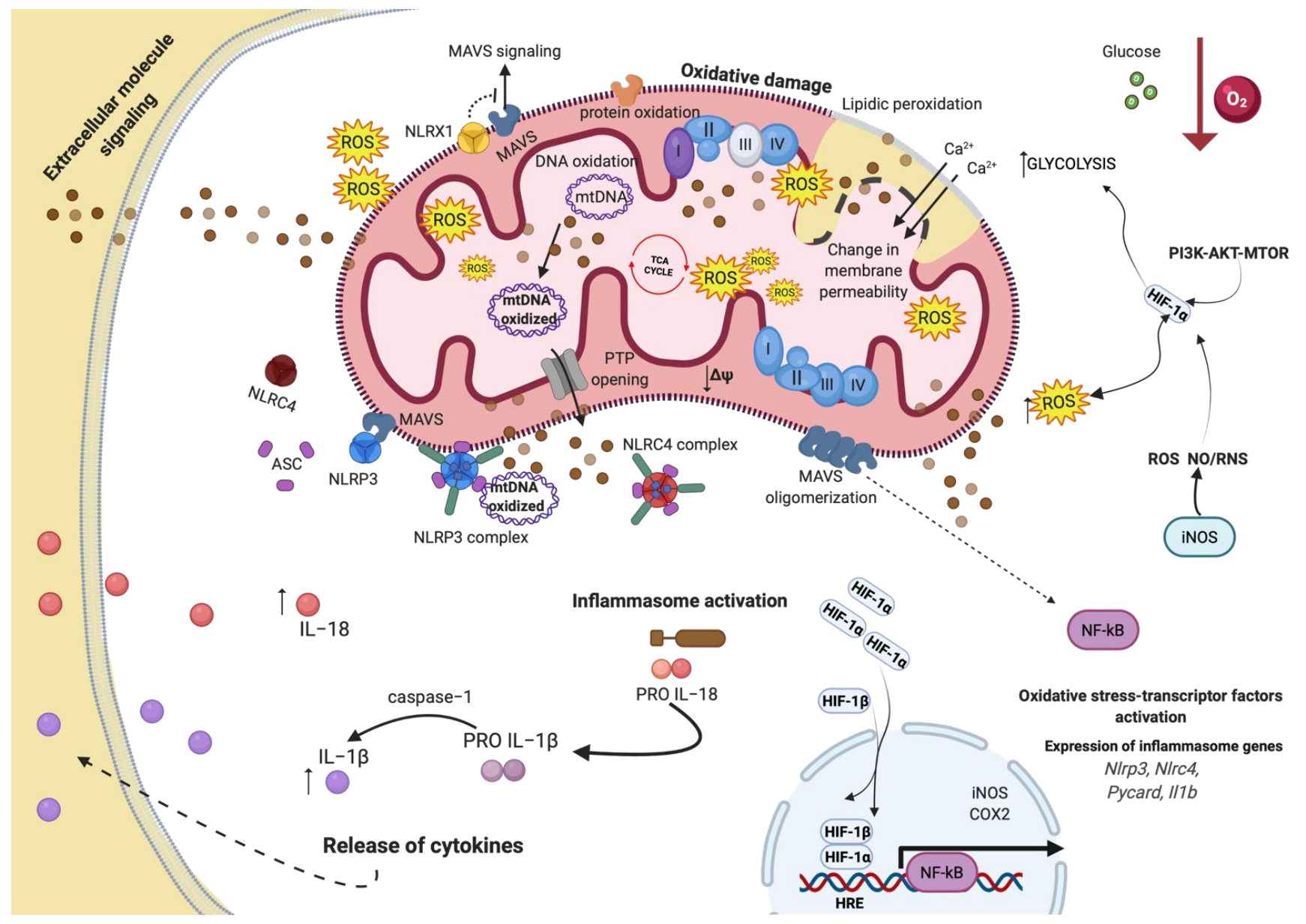

Figure 3. Inflammation and mitochondrial oxidative stress in response to hypoxic condition. During hypoxia, Hypoxic-inducible factor- $1 \alpha(\mathrm{HIF}-1 \alpha)$ stimulates the transcription of target genes involved in inflammation and oxidative stress-transcription factors. Moreover, HIF- $1 \alpha$ increased mitochondrial reactive oxygen species (mtROS) levels, activating nuclear factor kappa-light-chain-enhancer of activated B cells (NF-kB) transcription factor, stimulating the inflammasome genes expression, including NOD-, LRR- and pyrin domain-containing protein (NLRC) 4 , NLRP3, and interleukin $1 \beta$ (IL1 $\beta$ ) genes. Ultimately causing oxidative damage to the mitochondrial membrane, this event affects the membrane permeability, lipid peroxidation, and mtDNA, resulting in mitochondrial dysfunction. The FosfoInositide-3-Kinasi (PI3K)-protein kinase B (AKT)-mechanistic target of rapamycin (MTOR) pathway upregulates HIF-1 $\alpha$ during hypoxia.

\section{Novel Mechanisms and Therapeutic Targets in CVD and Cancer Disorders}

HIF-1 plays critical roles in important aspects of cancer biology to allow and promote tumor cells to grow and survive in response to hypoxic conditions, including invasion, 
metastasis, angiogenesis, modulation of glucose and energy metabolism, and stem cell maintenance. Therefore, the poor prognosis of cancer patients results in the actual interest in studying HIF- $1 \alpha$ as a therapeutic target in cancer disorder. Therefore, consistent with this concept, inhibiting HIF-1 or its related protein interactions has been demonstrated to block tumor proliferation. Different studies reported that HIF-1 inhibitors mitigate breast cancer metastasis in tumors sensitization to radiotherapy and mouse orthotopic transplant models [237,238]. Furthermore, several small molecules that repress HIF-1 directly or indirectly have been tested in clinical trials for different kinds of tumors [239].

By targeting HIF- $1 \alpha$, it is possible to intervene against malignant gliomas. Indeed, downregulation of HIF- $1 \alpha$ by siRNA decreases both the level of matrix metalloproteinase (MMP)-2 as well as the functions of MMP-2 and MMP-9 decreasing the mobility of glioma cell via the impaired invasion-related molecules [240].

Small molecules blocking the expression and the functions of HIF-1 have been found effective to reduce the growth of solid tumors such as prostate and breast cancer. An example is the RNA antagonist EZN-2968, which represses HIF-1 $\alpha$ mRNA expression [241] or PX-478, reduces the transcription of HIF-1 $\alpha$, blocks the translation through a VHL- and p53-independent pathway [242].

Furthermore, both PX-478 and EZN2968 elicit dose-dependent decreases in HIF-1 $\alpha$ levels and VEGF expression, as well as the tumor size in DU145 xenograft models, and both small-molecule inhibitors were well tolerated in clinical activities [241,242]. Other molecules identified include geldanamycin, which reduces the bond of the heat shock protein 90 (HSP90) to HIF-1 $\alpha$ to destabilize folding and increase proteasomal destruction [243]. Several HIF-1 $\alpha$ prolylhydroxylase inhibitors that preclude VHL from binding to HIF- $1 \alpha$ have also been developed and are now in late-stage clinical trials in disease in which HIF signaling is beneficial. For example, Roxadustat, which leads to increased endogenous erythropoietin generation, improved absorption of iron and anemia amelioration in chronic kidney disease (CKD) [244].

On the other hand, and in contrast to HIF-1 $\alpha$ effect on cancer as a stimulator for the disease's progression, HIF-1 $\alpha$ contributes to the cardiac protection in the majority of CVDs. This depends on the duration of hypoxia and the sustain of HIF-1 $\alpha$ activation. Different studies documented that the HIF-1 transcription factor displays a dual role in CVDs, as a protective effect in acute exposure to hypoxia, which is rapidly accumulated and stimulates a cascade of downstream target genes transcription involved in mitochondrial metabolism regulation, angiogenesis, and cell functions, leading to cardioprotection against ischemic insults. Moreover, these mechanisms regulate cellular functions in the hypoxic field to the sparsely oxygen environment and sustain normal cellular homeostasis, which under hypoxic stress is crucial for the human body. The HIF-1 pathway has a pivotal role in repairing cardiac tissue through the angiogenesis activation in I/R [245]. Thereby, it conveys a novel target to develop innovative therapies for the treatment of ischemic diseases and reduction of reperfusion injury [6]. Consistently, recent pieces of evidence reported the contribution of HIF-1 $\alpha$ in the therapeutic effect of certain natural compounds that attenuate myocardial I/R. One example may be found for Panax notoginseng saponins, which have protective roles against I/R via HIF-1 $\alpha$ /BCL2/BNIP3 pathway, which in return upregulates mitochondrial autophagy [246].

Nevertheless, HIF-1 contributes to the pathogenesis of various disorders during chronic exposure to hypoxia. HIF-1 is considered a promoter of atherosclerosis development, and for this reason, it may not be regarded as the disease's therapeutic treatment. Angiogenesis induced by HIF-1 transcription is protective in the short term, but then it forms collateral vessels that may result in terrible consequences in atherosclerosis patients. Nevertheless, this hypothesis is based on current research data, which are mostly focusing on the HIF-1 signaling pathway, particularly the HIF- $1 \alpha$ subunits. Further studies are needed on other members of the HIF family and the HIF- $1 \alpha$ subunits. At the physiological level, there are numerous mechanisms whose modulation by these transcription factors may have great potential for treating CVDs such as atherosclerosis [247]. Pulmonary hyper- 
tension $(\mathrm{PH})$ is another CVDs related to HIF-1 modulation. The proliferation of pulmonary arterial smooth muscle cells (PASMCs) and endothelial cells (Ecs) which are activated by HIF-1 and HIF-2 transcription, respectively, contributes toward the increase in pulmonary blood pressure [248]. Strategies that target the inhibition of HIF transcription in PH patients could be an interesting new perspective in the treatment of hypertension. Notably, it has been demonstrated that the HIF- $2 \alpha$ translation inhibitor compound 76 inhibits HIF- $2 \alpha$, and it is capable of relieving pulmonary artery blood pressure in different models [249].

\section{Conclusions and Future Perspectives}

The mechanism of cellular response to $\mathrm{O}_{2}$ deficiency is primarily regulated by the HIF- $1 \alpha$ pathway. Biological studies of HIF- $1 \alpha$ have improved the understanding of $\mathrm{O}_{2}$ homeostasis and notably gained much attention recently in many research fields. In this current review, we highlighted the effect of hypoxia on mitochondrial (dys)function and inflammation in CVDs and cancer.

We have evidenced how HIF- $1 \alpha$ signaling exhibits divergent effects in stimulating the disease progression or inducing protection after injury in different disease conditions. This dual role particularly happens when we consider HIF- $1 \alpha$ in CVDs and cancer. Indeed, meanwhile, HIF- $1 \alpha$ contributes to cardiac protection in the majority of CVDs, this hypoxic factor is highly associated to tumor progression, malignancy, and resistance to chemoradiation therapy. Regardless of these divergent effects, significant improvements of the scientific research have permitted to propose the targeting of HIF-1 $\alpha$ as a yielding strategy for the treatment of both CVDs and cancer.

Nevertheless, it is important to keep in mind key aspects when we are approaching treating cancer or CVDs with innovative therapies. Cancer progression contemplates different phases, which differ one from the other for several aspects. The term CVDs embraces at least 13 different conditions, which can affect both heart and blood vessels and that display its own clinical course. Furthermore, it is also fundamental to consider the heterogeneity caused by individual differences of the patients.

Only a deeper comprehension of the hypoxia-related mechanisms happening during the different phases of the tumor and in the single CVDs will really pave the way to endow and elucidate the great potential therapeutic targets and preventative approaches based on HIF- $1 \alpha$-modulation.

Author Contributions: E.B., S.P., G.M., A.E.K., M.P., M.D.S. and M.R.W. wrote the manuscript with input from P.P., C.G., E.B., and M.D.S. prepared display items (with https:/ / biorender.com (accessed on 21 January 2022)) The figures are original and have not been published before. F.F., P.P., S.P. and C.G. reviewed the manuscript before submission. All authors have read and agreed to the published version of the manuscript.

Funding: P.P. is grateful to Camilla degli Scrovegni for continuous support. The Signal Transduction Laboratory is supported by the Italian Association for Cancer Research (AIRC; Grant IG-23670 to P.P. and Grant IG-19803 to C.G.), Associazione Ricerca Oncologica Sperimentale Estense (A-ROSE), Telethon (Grant GGP11139B to P.P.), the Ministry of Education, University and Research-Progetti di Rilevante Interesse Nazionale (Grant PRIN2017E5L5P3 to P.P. and Grant PRIN20177E9EPY to C.G.), the Italian Ministry of Health (Grant GR-2013-02356747 to C.G. and GR-2019-12369862 to G.M.), the European Research Council (Grant InflaPML 853057 to C.G.), and by local funds from the University of Ferrara to P.P. and C.G. M.R.W. was supported by the National Science Centre, Poland (Grant UMO-2018/29/B/NZ1/00589).

Institutional Review Board Statement: Not applicable.

Informed Consent Statement: Not applicable.

Data Availability Statement: Not applicable.

Conflicts of Interest: The authors declare no conflict of interest. 
Abbreviations

\begin{tabular}{|c|c|}
\hline 2-HG & 2-hydroxyglutarate \\
\hline $2-\mathrm{OG}$ & 2-oxoglutarate \\
\hline 4-HNE & 4-hydroxynonenal \\
\hline AKAP121 & A-kinase anchor protein 1 \\
\hline $\mathrm{APC}$ & Adenomatosis Polyposis Coli \\
\hline ARNT & Aryl hydrocarbon receptor nuclear translocator \\
\hline ATP & Adenosine triphosphate \\
\hline BAP1 & BRCA1-associated protein 1 \\
\hline bHLH & Basic helix-loop-helix \\
\hline BNIP3 & BCL2 and adenovirus E1B 19-kD-interacting protein 3 \\
\hline $\mathrm{C} 26$ & Colon cancer \\
\hline $\mathrm{Ca}^{2+}$ & Calcium \\
\hline CAD & Coronary artery disease \\
\hline $\mathrm{CBP} / \mathrm{p} 300$ & CREB-binding protein \\
\hline $\mathrm{CC}$ & Cancer cachexia \\
\hline $\mathrm{CCHD}$ & Cyanotic congenital heart disease \\
\hline CCL-39 & Chinese hamster Lung fibroblasts \\
\hline $\mathrm{CH}$ & Chronic hypoxia \\
\hline $\mathrm{CHD}$ & Coronary heart disease \\
\hline CKD & Chronic kidney disease \\
\hline CPT1A & Carnitine palmitoyltransferase $1 \mathrm{~A}$ \\
\hline CVD & Cardiovascular disease \\
\hline DFO & Deferoxamine \\
\hline DRP1 & Dynamin-related protein 1 \\
\hline Ecs & Endothelial cells \\
\hline $\mathrm{EPO}$ & Erythropoietin \\
\hline ER & Endoplasmic reticulum \\
\hline ERK1/2 & Extracellular signal-regulated kinase $\frac{1}{2}$ \\
\hline FAO & Fatty acid oxidation \\
\hline $\mathrm{FIH}$ & Inhibiting HIF \\
\hline Fis 1 & Fission 1 mitochondrial protein \\
\hline FTH & Ferritin Heavy Chain \\
\hline FUNDC1 & FUN14 Domain Containing 1 \\
\hline GCLM & Glutamate-cysteine ligase \\
\hline $\mathrm{H}_{2} \mathrm{O}_{2}$ & Hydrogen peroxide \\
\hline $\mathrm{HCC}$ & Hepatocellular carcinoma \\
\hline HCT 116 & Human colorectal carcinoma \\
\hline $\mathrm{HF}$ & Heart failure \\
\hline HIF-1 & Hypoxic-inducible factor-1 \\
\hline HIF-1 $\alpha$ & Hypoxia-inducible factor 1-alpha \\
\hline HMGB1 & High mobility group box 1 \\
\hline HREs & Hypoxic-responsive elements \\
\hline HSP70 & Heat shock protein 70 \\
\hline HSP90 & Heat shock protein 90 \\
\hline HUVEC & Human umbilical vein endothelial \\
\hline IHD & Ischemic heart disease \\
\hline IMM & Inner mitochondrial membrane \\
\hline IMS & Mitochondrial intermembrane space \\
\hline iNOS & Inducible nitric oxide synthase \\
\hline ISCU & Iron-Sulfur Cluster Assembly Enzyme \\
\hline JAK2/STAT3 & Janus kinase/signal transducer and activator of transcription \\
\hline KRAS & GTPase Kras \\
\hline LDH-A & Lactate dehydrogenase-A \\
\hline $\mathrm{LDH}$ & Lactate dehydrogenase \\
\hline LPS & Lipopolysaccharide \\
\hline LS174 & Human colonic adenocarcinoma cells \\
\hline
\end{tabular}




\begin{tabular}{|c|c|}
\hline LV & Left ventricle \\
\hline MAMs & Mitochondria-associated membranes \\
\hline MAOs & Monoamine oxidases \\
\hline MCF-7 & Human breast cancer cells \\
\hline MCU & Mitochondrial calcium uniporter \\
\hline $\mathrm{MDH}$ & Malate dehydrogenase \\
\hline MECs & mammary epithelial cells \\
\hline mETC & Mitochondrial electron respiratory chain \\
\hline MFN1 & Mitofusin 1 \\
\hline MI & Myocardial infarction \\
\hline miRs & MicroRNAs \\
\hline MLKL & Mixed lineage kinase domain-like \\
\hline MMP-2 & Matrix metalloproteinase \\
\hline MMP & Mitochondrial membrane potential \\
\hline MMTV-PyMT & Mouse mammary tumor virus-polyoma middle tumor-antigen \\
\hline $\mathrm{mPTP}$ & Mitochondrial permeability transition pore \\
\hline MTOR & Rapamycin inhibitor rapamycin \\
\hline mtROS & Mitochondrial ROS \\
\hline MXI1 & MAX-interactor 1 \\
\hline NLRs & Leucine-rich repeat-containing receptors \\
\hline NOXs & NADPH oxidases \\
\hline NRFs & Nuclear respiratory factors \\
\hline $\mathrm{O}_{2}^{-}$ & Superoxide \\
\hline $\mathrm{O}_{2}$ & Oxygen \\
\hline ODDD & Oxygen-dependent degradation domain \\
\hline OMM & Outer mitochondrial membrane \\
\hline OSCC & Oral squamous cell carcinoma \\
\hline OXPHOS & Oxidative phosphorylation \\
\hline p70S6K & Phospho-p70 S6 Kinase \\
\hline PAD & Peripheral arterial diseases \\
\hline PASMCs & Pulmonary arterial smooth muscle cells \\
\hline PCR & Polymerase chain reaction \\
\hline $\mathrm{PH}$ & Pulmonary hypertension \\
\hline PHDs & Propyl-hydroxylases \\
\hline PGC- $1 \alpha$ & peroxisome proliferator-activated receptor gamma coactivator 1-alpha \\
\hline $\mathrm{PI} 3 \mathrm{~K} / \mathrm{AKT}$ & Phosphoinositide-3-kinase/Akt \\
\hline PKA & Protein kinase A \\
\hline PKM2 & M2 isoform of pyruvate kinase \\
\hline $\mathrm{PRX} / \operatorname{Tr} \mathrm{x}$ & peroxiredoxin/thioredoxin \\
\hline pVHL & Von Hippel-Lindau \\
\hline RIP1, 3 & Receptor-interacting protein 1,3 \\
\hline RNS & Reactive nitrogen species \\
\hline ROS & Reactive oxygen species \\
\hline SLC7A11 & Solute carrier family 7-member 11 \\
\hline SOD & Superoxide dismutase \\
\hline SUM-149 & Triple-negative breast cancer cells \\
\hline TCA & Tricarboxylic acid \\
\hline TFR1 & transferrin receptor 1 \\
\hline TGF- $\beta$ & Transforming growth factor beta \\
\hline TNBC & Triple negative breast cancer \\
\hline TNF & Tumor necrosis factor \\
\hline TRAF6 & Receptor-associated factor 6 \\
\hline Tregs & regulatory $\mathrm{T}$ cells \\
\hline VDAC1 & Voltage-dependent anion-selective channel 1 \\
\hline VGF-A & vascular endothelial growth factor-A \\
\hline WDR26 & WD Repeat Domain 26 \\
\hline WNT & Wingless-related integration site \\
\hline$\Delta \Psi_{\mathrm{m}}$ & Mitochondrial membrane potential \\
\hline
\end{tabular}




\section{References}

1. Masoudkabir, F.; Sarrafzadegan, N.; Gotay, C.; Ignaszewski, A.; Krahn, A.D.; Davis, M.K.; Franco, C.; Mani, A. Cardiovascular disease and cancer: Evidence for shared disease pathways and pharmacologic prevention. Atherosclerosis 2017, 263, 343-351. [CrossRef] [PubMed]

2. Gernaat, S.A.M.; Boer, J.M.A.; Bongard, D.V.D.; Maas, A.H.E.M.; Van Der Pol, C.C.; Bijlsma, R.M.; Grobbee, D.E.; Verkooijen, H.M.; Peeters, P.H. The risk of cardiovascular disease following breast cancer by Framingham risk score. Breast Cancer Res. Treat. 2018, 170, 119-127. [CrossRef] [PubMed]

3. Coviello, J.S. Cardiovascular and Cancer Risk: The Role of Cardio-oncology. J. Adv. Pr. Oncol. 2018, 9, $160-176$.

4. $\quad$ De Boer, R.A.; Meijers, W.C.; Van Der Meer, P.; Van Veldhuisen, D.J. Cancer and heart disease: Associations and relations. Eur. J. Hear. Fail. 2019, 21, 1515-1525. [CrossRef] [PubMed]

5. Waypa, G.B.; Smith, K.A.; Schumacker, P.T. $\mathrm{O}_{2}$ sensing, mitochondria and ROS signaling: The fog is lifting. Mol. Asp. Med. 2016, 47-48, 76-89. [CrossRef] [PubMed]

6. $\quad$ Liu, M.; Galli, G.; Wang, Y.; Fan, Q.; Wang, Z.; Wang, X.; Xiao, W. Novel Therapeutic Targets for Hypoxia-Related Cardiovascular Diseases: The Role of HIF-1. Front. Physiol. 2020, 11, 774. [CrossRef]

7. Bousquet, P.A.; Meltzer, S.; Sønstevold, L.; Esbensen, Y.; Dueland, S.; Flatmark, K.; Sitter, B.; Bathen, T.F.; Seierstad, T.; Redalen, K.R.; et al. Markers of Mitochondrial Metabolism in Tumor Hypoxia, Systemic Inflammation, and Adverse Outcome of Rectal Cancer. Transl. Oncol. 2019, 12, 76-83. [CrossRef]

8. Chen, P.-S.; Chiu, W.-T.; Hsu, P.-L.; Lin, S.-C.; Peng, I.-C.; Wang, C.-Y.; Tsai, S.-J. Pathophysiological implications of hypoxia in human diseases. J. Biomed. Sci. 2020, 27, 1-19. [CrossRef]

9. Kim, J.-W.; Tchernyshyov, I.; Semenza, G.L.; Dang, C.V. HIF-1-mediated expression of pyruvate dehydrogenase kinase: A metabolic switch required for cellular adaptation to hypoxia. Cell Metab. 2006, 3, 177-185. [CrossRef]

10. McClelland, G.B.; Brooks, G.A. Changes in MCT 1, MCT 4, and LDH expression are tissue specific in rats after long-term hypobaric hypoxia. J. Appl. Physiol. 2002, 92, 1573-1584. [CrossRef]

11. Tuder, R.M.; E Flook, B.; Voelkel, N.F. Increased gene expression for VEGF and the VEGF receptors KDR/Flk and Flt in lungs exposed to acute or to chronic hypoxia. Modulation of gene expression by nitric oxide. J. Clin. Investig. 1995, 95, 1798-1807. [CrossRef] [PubMed]

12. Semenza, G.L.; Wang, G.L. A nuclear factor induced by hypoxia via de novo protein synthesis binds to the human erythropoietin gene enhancer at a site required for transcriptional activation. Mol. Cell. Biol. 1992, 12, 5447-5454. [CrossRef]

13. Melillo, G.; Musso, T.; Sica, A.; Taylor, L.S.; Cox, G.W.; Varesio, L. A hypoxia-responsive element mediates a novel pathway of activation of the inducible nitric oxide synthase promoter. J. Exp. Med. 1995, 182, 1683-1693. [CrossRef]

14. Semenza, G.L. Hypoxia-Inducible Factor 1 (HIF-1) Pathway. Sci. STKE 2007, 2007, cm8. [CrossRef]

15. Nakayama, K.; Kataoka, N. Regulation of Gene Expression under Hypoxic Conditions. Int. J. Mol. Sci. 2019, 20, 3278. [CrossRef]

16. Wang, G.L.; Semenza, G.L. Purification and Characterization of Hypoxia-inducible Factor 1. J. Biol. Chem. 1995, $270,1230-1237$. [CrossRef] [PubMed]

17. Semenza, G.L. Hypoxia-Inducible Factors in Physiology and Medicine. Cell 2012, 148, 399-408. [CrossRef]

18. Semenza, G.L. Hypoxia-inducible factor 1: Regulator of mitochondrial metabolism and mediator of ischemic preconditioning. Biochim. Biophys. Acta 2011, 1813, 1263-1268. [CrossRef]

19. Lee, D.C.; Sohn, H.A.; Park, Z.-Y.; Oh, S.; Kang, Y.K.; Lee, K.-M.; Kang, M.; Jang, Y.J.; Yang, S.-J.; Hong, Y.K.; et al. A LactateInduced Response to Hypoxia. Cell 2015, 161, 595-609. [CrossRef]

20. Zheng, J.; Chen, P.; Zhong, J.; Cheng, Y.; Chen, H.; He, Y.; Chen, C. HIF-1 $\alpha$ in myocardial ischemia-reperfusion injury (Review). Mol. Med. Rep. 2021, 23, 1-9. [CrossRef] [PubMed]

21. Ke, Q.; Costa, M. Hypoxia-Inducible Factor-1 (HIF-1). Mol. Pharmacol. 2006, 70, 1469-1480. [CrossRef] [PubMed]

22. Jiang, B.-H.; Rue, E.; Wang, G.L.; Roe, R.; Semenza, G.L. Dimerization, DNA Binding, and Transactivation Properties of Hypoxia-inducible Factor 1. J. Biol. Chem. 1996, 271, 17771-17778. [CrossRef] [PubMed]

23. Wang, G.L.; Jiang, B.-H.; Rue, E.A.; Semenza, G.L. Hypoxia-inducible factor 1 is a basic-helix-loop-helix-PAS heterodimer regulated by cellular $\mathrm{O}_{2}$ tension. Proc. Natl. Acad. Sci. USA 1995, 92, 5510-5514. [CrossRef] [PubMed]

24. Bruick, R.K.; McKnight, S.L. A Conserved Family of Prolyl-4-Hydroxylases That Modify HIF. Science 2001, $294,1337-1340$. [CrossRef] [PubMed]

25. Jaakkola, P.; Mole, D.R.; Tian, Y.-M.; Wilson, M.I.; Gielbert, J.; Gaskell, S.J.; von Kriegsheim, A.; Hebestreit, H.F.; Mukherji, M.; Schofield, C.J.; et al. Targeting of HIF-alpha to the von Hippel-Lindau Ubiquitylation Complex by $\mathrm{O}_{2}$-Regulated Prolyl Hydroxylation. Science 2001, 292, 468-472. [CrossRef]

26. Luo, W.; Hu, H.; Chang, R.; Zhong, J.; Knabel, M.; O'Meally, R.; Cole, R.N.; Pandey, A.; Semenza, G.L. Pyruvate Kinase M2 Is a PHD3-Stimulated Coactivator for Hypoxia-Inducible Factor 1. Cell 2011, 145, 732-744. [CrossRef]

27. Tian, X.; Zhou, N.; Yuan, J.; Lu, L.; Zhang, Q.; Wei, M.; Zou, Y.; Yuan, L. Heat shock transcription factor 1 regulates exerciseinduced myocardial angiogenesis after pressure overload via HIF-1 $\alpha$ /VEGF pathway. J. Cell. Mol. Med. 2020, 24, 2178-2188. [CrossRef]

28. Hölscher, M.; Schäfer, K.; Krull, S.; Farhat, K.; Hesse, A.; Silter, M.; Lin, Y.; Pichler, B.J.; Thistlethwaite, P.; El-Armouche, A.; et al. Unfavourable consequences of chronic cardiac HIF-1 $\alpha$ stabilization. Cardiovasc. Res. 2012, 94, 77-86. [CrossRef] 
29. Zhang, Y.; Xu, Y.; Zhou, K.; Kao, G.; Yan, M.; Xiao, J. Hypoxia-inducible transcription factor-1 $\alpha$ inhibition by topotecan protects against lipopolysaccharide-induced inflammation and apoptosis of cardiomyocytes. BioMed. Eng. OnLine 2021, 20, 88. [CrossRef] [PubMed]

30. Xie, L.; Pi, X.; Wang, Z.; He, J.; Willis, M.S.; Patterson, C. Depletion of PHD3 protects heart from ischemia/reperfusion injury by inhibiting cardiomyocyte apoptosis. J. Mol. Cell. Cardiol. 2015, 80, 156-165. [CrossRef]

31. Neckar, J.; Hsu, A.; Khan, A.H.; Gross, G.J.; Nithipatikom, K.; Cyprova, M.; Benak, D.; Hlavackova, M.; Sotáková-Kašparová, D.; Falck, J.R.; et al. Infarct size-limiting effect of epoxyeicosatrienoic acid analog EET-B is mediated by hypoxia-inducible factor- $1 \alpha$ via downregulation of prolyl hydroxylase 3. Am. J. Physiol. Circ. Physiol. 2018, 315, H1148-H1158. [CrossRef]

32. Date, T.; Mochizuki, S.; Belanger, A.J.; Yamakawa, M.; Luo, Z.; Vincent, K.A.; Cheng, S.H.; Gregory, R.J.; Jiang, C. Expression of constitutively stable hybrid hypoxia-inducible factor- $1 \alpha$ protects cultured rat cardiomyocytes against simulated ischemiareperfusion injury. Am. J. Physiol. Physiol. 2005, 288, C314-C320. [CrossRef]

33. Morand, J.; Arnaud, C.; Pépin, J.L.; Godin-Ribuot, D. Chronic intermittent hypoxia promotes myocardial ischemia-related ventricular arrhythmias and sudden cardiac death. Sci. Rep. 2018, 8, 1-8. [CrossRef]

34. Meerson, F.Z.; Beloshitskiü, P.V.; Vorontsova, E.I.; Ustinova, E.E.; Rozhitskaia, I.I. Effect of adaptation to continuous and intermittent hypoxia on heart resistance to ischemic and reperfusion arrhythmias. Patol. Fiziol. Eksp Ter. 1989, 48-50. (In Russian)

35. Belaidi, E.; Béguin, P.C.; Lévy, P.; Ribuot, C.; Godin-Ribuot, D. Prevention of HIF-1 activation and iNOS gene targeting by low-dose cadmium results in loss of myocardial hypoxic preconditioning in the rat. Am. J. Physiol. Circ. Physiol. 2008, 294, H901-H908. [CrossRef]

36. Xi, L.; Tekin, D.; Gursoy, E.; Salloum, F.; Levasseur, J.E.; Kukreja, R.C. Evidence that NOS2 acts as a trigger and mediator of late preconditioning induced by acute systemic hypoxia. Am. J. Physiol. Circ. Physiol. 2002, 283, H5-H12. [CrossRef]

37. Ding, H.-L.; Zhu, H.-F.; Dong, J.-W.; Zhu, W.-Z.; Yang, W.-W.; Yang, H.-T.; Zhou, Z.-N. Inducible nitric oxide synthase contributes to intermittent hypoxia against ischemia/reperfusion injury1. Acta Pharmacol. Sin. 2005, 26, 315-322. [CrossRef] [PubMed]

38. Minamishima, Y.A.; Moslehi, J.; Bardeesy, N.; Cullen, D.; Bronson, R.T.; Kaelin, W.G. Somatic inactivation of the PHD2 prolyl hydroxylase causes polycythemia and congestive heart failure. Blood 2008, 111, 3236-3244. [CrossRef] [PubMed]

39. Zhang, Y.; Liu, D.; Hu, H.; Zhang, P.; Xie, R.; Cui, W. HIF-1 $\alpha$ /BNIP3 signaling pathway-induced-autophagy plays protective role during myocardial ischemia-reperfusion injury. Biomed. Pharmacother. 2019, 120, 109464. [CrossRef] [PubMed]

40. Chen, Y.-F.; Pandey, S.; Day, C.H.; Chen, Y.-F.; Jiang, A.-Z.; Ho, T.-J.; Chen, R.-J.; Padma, V.V.; Kuo, W.-W.; Huang, C.-Y. Synergistic effect of HIF-1 $\alpha$ and FoxO3a trigger cardiomyocyte apoptosis under hyperglycemic ischemia condition. J. Cell. Physiol. 2018, 233, 3660-3671. [CrossRef]

41. Dorn, G.W.; Kirshenbaum, L.A. Cardiac reanimation: Targeting cardiomyocyte death by BNIP3 and NIX/BNIP3L. Oncogene 2008, 27, S158-S167. [CrossRef]

42. Xin, T.; Lv, W.; Liu, D.; Jing, Y.; Hu, F. Opa1 Reduces Hypoxia-Induced Cardiomyocyte Death by Improving Mitochondrial Quality Control. Front. Cell Dev. Biol. 2020, 8, 853. [CrossRef]

43. Zhou, H.; Zhu, P.; Wang, J.; Zhu, H.; Ren, J.; Chen, Y. Pathogenesis of cardiac ischemia reperfusion injury is associated with CK2 $\alpha$-disturbed mitochondrial homeostasis via suppression of FUNDC1-related mitophagy. Cell Death Differ. 2018, 25, 1080-1093. [CrossRef]

44. Zhou, H.; Zhu, P.; Guo, J.; Hu, N.; Wang, S.; Li, D.; Hu, S.; Ren, J.; Cao, F.; Chen, Y. Ripk3 induces mitochondrial apoptosis via inhibition of FUNDC1 mitophagy in cardiac IR injury. Redox Biol. 2017, 13, 498-507. [CrossRef] [PubMed]

45. Feng, Y.; Zhao, J.; Hou, H.; Zhang, H.; Jiao, Y.; Wang, J.; Wang, Y.; Sun, Y. WDR26 promotes mitophagy of cardiomyocytes induced by hypoxia through Parkin translocation. Acta Biochim. Biophys. Sin. 2016, 48, 1075-1084. [CrossRef]

46. Zhao, J.-F.; Rodger, C.E.; Allen, G.F.G.; Weidlich, S.; Ganley, I.G. HIF1 $\alpha$-dependent mitophagy facilitates cardiomyoblast differentiation. Cell Stress 2020, 4, 99-113. [CrossRef] [PubMed]

47. Chowdhury, A.; Aich, A.; Jain, G.; Wozny, K.; Lüchtenborg, C.; Hartmann, M.; Bernhard, O.; Balleiniger, M.; Alfar, E.A.; Zieseniss, A.; et al. Defective Mitochondrial Cardiolipin Remodeling Dampens HIF-1 $\alpha$ Expression in Hypoxia. Cell Rep. 2018, 25, 561-570.e6. [CrossRef] [PubMed]

48. Papandreou, I.; Cairns, R.A.; Fontana, L.; Lim, A.L.; Denko, N.C. HIF-1 mediates adaptation to hypoxia by actively downregulating mitochondrial oxygen consumption. Cell Metab. 2006, 3, 187-197. [CrossRef] [PubMed]

49. Gomes, A.P.; Price, N.L.; Ling, A.J.Y.; Moslehi, J.J.; Montgomery, M.K.; Rajman, L.; White, J.P.; Teodoro, J.S.; Wrann, C.D.; Hubbard, B.P.; et al. Declining NAD+ Induces a Pseudohypoxic State Disrupting Nuclear-Mitochondrial Communication during Aging. Cell 2013, 155, 1624-1638. [CrossRef]

50. Fuhrmann, D.; Brüne, B. Mitochondrial composition and function under the control of hypoxia. Redox Biol. 2017, 12, 208-215. [CrossRef] [PubMed]

51. Koutnikova, H.; Campuzano, V.; Foury, F.; Dollé, P.; Cazzalini, O.; Koenig, M. Studies of human, mouse and yeast homologues indicate a mitochondrial function for frataxin. Nat. Genet. 1997, 16, 345-351. [CrossRef]

52. Nanayakkara, G.; Alasmari, A.; Mouli, S.; Eldoumani, H.; Quindry, J.C.; McGinnis, G.; Fu, X.; Berlin, A.; Peters, B.; Zhong, J.; et al. Cardioprotective HIF-1 $\alpha$-frataxin signaling against ischemia-reperfusion injury. Am. J. Physiol. Circ. Physiol. 2015, 309, H867-H879. [CrossRef] [PubMed] 
53. Rane, S.; He, M.; Sayed, D.; Vashistha, H.; Malhotra, A.; Sadoshima, J.; Vatner, D.E.; Vatner, S.F.; Abdellatif, M. Downregulation of MiR-199a Derepresses Hypoxia-Inducible Factor- $1 \alpha$ and Sirtuin 1 and Recapitulates Hypoxia Preconditioning in Cardiac Myocytes. Circ. Res. 2009, 104, 879-886. [CrossRef] [PubMed]

54. Briston, T.; Yang, J.; Ashcroft, M. HIF-1 $\alpha$ localization with mitochondria. Cell Cycle 2011, 10, 4170-4171. [CrossRef] [PubMed]

55. Mylonis, I.; Kourti, M.; Samiotaki, M.; Panayotou, G.; Simos, G. Mortalin-mediated and ERK-controlled targeting of HIF-1 $\alpha$ to mitochondria confers resistance to apoptosis under hypoxia. J. Cell Sci. 2017, 130, 466-479. [CrossRef] [PubMed]

56. Li, H.-S.; Zhou, Y.-N.; Li, L.; Li, S.-F.; Long, D.; Chen, X.-L.; Zhang, J.-B.; Feng, L.; Li, Y.-P. HIF-1 $\alpha$ protects against oxidative stress by directly targeting mitochondria. Redox Biol. 2019, 25, 101109. [CrossRef]

57. Du, Y.; Ge, Y.; Xu, Z.-H.; Aa, N.; Gu, X.; Meng, H.; Lin, Z.; Zhu, N.; Shi, J.; Zhuang, R.; et al. Hypoxia-Inducible Factor 1 alpha (HIF-1 $\alpha$ )/Vascular Endothelial Growth Factor (VEGF) Pathway Participates in Angiogenesis of Myocardial Infarction in Muscone-Treated Mice: Preliminary Study. Med. Sci. Monit. 2018, 24, 8870-8877. [CrossRef]

58. Ikeda, M.; Ide, T.; Tadokoro, T.; Miyamoto, H.D.; Ikeda, S.; Okabe, K.; Ishikita, A.; Sato, M.; Abe, K.; Furusawa, S.; et al. Excessive Hypoxia-Inducible Factor- $1 \alpha$ Expression Induces Cardiac Rupture via p53-Dependent Apoptosis After Myocardial Infarction. J. Am. Hear. Assoc. 2021, 10, 020895. [CrossRef]

59. Liu, Y.; Zeng, L.; Yang, Y.; Chen, C.; Wang, D.; Wang, H. Acyl-CoA thioesterase 1 prevents cardiomyocytes from Doxorubicininduced ferroptosis via shaping the lipid composition. Cell Death Dis. 2020, 11, 756. [CrossRef]

60. Wei, H.; Bedja, D.; Koitabashi, N.; Xing, D.; Chen, J.; Fox-Talbot, K.; Rouf, R.; Chen, S.; Steenbergen, C.; Harmon, J.W.; et al. Endothelial expression of hypoxia-inducible factor 1 protects the murine heart and aorta from pressure overload by suppression of TGF- signaling. Proc. Natl. Acad. Sci. 2012, 109, E841-E850. [CrossRef]

61. Stamati, K.; Mudera, V.; Cheema, U. Evolution of oxygen utilization in multicellular organisms and implications for cell signalling in tissue engineering. J. Tissue Eng. 2011, 2, 2041731411432365. [CrossRef]

62. Wolff, M.; Kosyna, F.K.; Dunst, J.; Jelkmann, W.; Depping, R. Impact of hypoxia inducible factors on estrogen receptor expression in breast cancer cells. Arch. Biochem. Biophys. 2017, 613, 23-30. [CrossRef]

63. Nadtochiy, S.M.; Schafer, X.; Fu, D.; Nehrke, K.; Munger, J.; Brookes, P.S. Acidic pH Is a Metabolic Switch for 2-Hydroxyglutarate Generation and Signaling. J. Biol. Chem. 2016, 291, 20188-20197. [CrossRef]

64. Miska, J.; Lee-Chang, C.; Rashidi, A.; Muroski, M.E.; Chang, A.L.; Lopez-Rosas, A.; Zhang, P.; Panek, W.K.; Cordero, A.; Han, Y.; et al. HIF-1 $\alpha$ Is a Metabolic Switch between Glycolytic-Driven Migration and Oxidative Phosphorylation-Driven Immunosuppression of Tregs in Glioblastoma. Cell Rep. 2019, 27, 226-237.e4. [CrossRef] [PubMed]

65. Fukuda, R.; Zhang, H.; Kim, J.-W.; Shimoda, L.; Dang, C.V.; Semenza, G.L. HIF-1 Regulates Cytochrome Oxidase Subunits to Optimize Efficiency of Respiration in Hypoxic Cells. Cell 2007, 129, 111-122. [CrossRef] [PubMed]

66. Rodríguez-Enríquez, S.; Carreño-Fuentes, L.; Gallardo-Pérez, J.C.; Saavedra, E.; Quezada, H.; Vega, A.; Marín-Hernández, A.; Olín-Sandoval, V.; Torres-Márquez, M.E.; Moreno-Sánchez, R. Oxidative phosphorylation is impaired by prolonged hypoxia in breast and possibly in cervix carcinoma. Int. J. Biochem. Cell Biol. 2010, 42, 1744-1751. [CrossRef] [PubMed]

67. Chan, S.Y.; Zhang, Y.-Y.; Hemann, C.; Mahoney, C.E.; Zweier, J.L.; Loscalzo, J. MicroRNA-210 Controls Mitochondrial Metabolism during Hypoxia by Repressing the Iron-Sulfur Cluster Assembly Proteins ISCU1/2. Cell Metab. 2009, 10, 273-284. [CrossRef]

68. Guarino, F.; Zinghirino, F.; Mela, L.; Pappalardo, X.G.; Ichas, F.; De Pinto, V.; Messina, A. NRF-1 and HIF-1 $\alpha$ contribute to modulation of human VDAC1 gene promoter during starvation and hypoxia in HeLa cells. Biochim. Biophys. Acta 2020, 1861, 148289. [CrossRef] [PubMed]

69. Zhang, H.; Gao, P.; Fukuda, R.; Kumar, G.; Krishnamachary, B.; Zeller, K.I.; Dang, C.; Semenza, G.L. HIF-1 Inhibits Mitochondrial Biogenesis and Cellular Respiration in VHL-Deficient Renal Cell Carcinoma by Repression of C-MYC Activity. Cancer Cell 2007, 11, 407-420. [CrossRef] [PubMed]

70. Tohme, S.; Yazdani, H.O.; Liu, Y.; Loughran, P.; Van Der Windt, D.J.; Huang, H.; Simmons, R.L.; Shiva, S.; Tai, S.; Tsung, A. Hypoxia mediates mitochondrial biogenesis in hepatocellular carcinoma to promote tumor growth through HMGB1 and TLR9 interaction. Hepatol. 2017, 66, 182-197. [CrossRef]

71. Jin, J.; Qiu, S.; Wang, P.; Liang, X.; Huang, F.; Wu, H.; Zhang, B.; Zhang, W.; Tian, X.; Xu, R.; et al. Cardamonin inhibits breast cancer growth by repressing HIF-1 $\alpha$-dependent metabolic reprogramming. J. Exp. Clin. Cancer Res. 2019, 38, 1-16. [CrossRef] [PubMed]

72. Lu, H.; Samanta, D.; Xiang, L.; Zhang, H.; Hu, H.; Chen, I.; Bullen, J.W.; Semenza, G.L. Chemotherapy triggers HIF-1-dependent glutathione synthesis and copper chelation that induces the breast cancer stem cell phenotype. Proc. Natl. Acad. Sci. 2015, 112, E4600-E4609. [CrossRef] [PubMed]

73. Chourasia, A.H.; Tracy, K.; Frankenberger, C.; Boland, M.L.; Sharifi, M.; E Drake, L.; Sachleben, J.R.; Asara, J.M.; Locasale, J.; Karczmar, G.S.; et al. Mitophagy defects arising from BNip3 loss promote mammary tumor progression to metastasis. EMBO Rep. 2015, 16, 1145-1163. [CrossRef] [PubMed]

74. Castelli, S.; Ciccarone, F.; Tavian, D.; Ciriolo, M.R. ROS-dependent HIF1 $\alpha$ activation under forced lipid catabolism entails glycolysis and mitophagy as mediators of higher proliferation rate in cervical cancer cells. J. Exp. Clin. Cancer Res. 2021, 40, 1-18. [CrossRef] [PubMed]

75. Wu, Z.; Zuo, M.; Zeng, L.; Cui, K.; Liu, B.; Yan, C.; Chen, L.; Dong, J.; Shangguan, F.; Hu, W.; et al. OMA1 reprograms metabolism under hypoxia to promote colorectal cancer development. EMBO Rep. 2021, 22, e50827. [CrossRef] 
76. Chiche, J.; Rouleau, M.; Gounon, P.; Brahimi-Horn, M.C.; Pouyssã@Gur, J.; Mazure, N.M. Hypoxic enlarged mitochondria protect cancer cells from apoptotic stimuli. J. Cell. Physiol. 2009, 222, 648-657. [CrossRef]

77. Devine, R.; Bicer, S.; Reiser, P.J.; Wold, L.E. Increased hypoxia-inducible factor- $1 \alpha$ in striated muscle of tumor-bearing mice. Am. J. Physiol. Circ. Physiol. 2017, 312, H1154-H1162. [CrossRef] [PubMed]

78. Wu, C.-S.; Chang, I.Y.-F.; Hung, J.-L.; Liao, W.-C.; Lai, Y.-R.; Chang, K.-P.; Li, H.-P.; Chang, Y.-S. ASC modulates HIF-1 $\alpha$ stability and induces cell mobility in OSCC. Cell Death Dis. 2020, 11, 1-11. [CrossRef] [PubMed]

79. Coimbra-Costa, D.; Alva, N.; Duran, M.; Carbonell, T.; Rama, R. Oxidative stress and apoptosis after acute respiratory hypoxia and reoxygenation in rat brain. Redox Biol. 2017, 12, 216-225. [CrossRef] [PubMed]

80. Liberti, M.V.; Locasale, J.W. The Warburg Effect: How Does it Benefit Cancer Cells? Trends Biochem. Sci. 2016, 41, 211-218. [CrossRef]

81. Akkol, E.; Tatlı, I.; Karatoprak, G.; Ağar, O.; Yücel, Ç.; Sobarzo-Sánchez, E.; Capasso, R. Is Emodin with Anticancer Effects Completely Innocent? Two Sides of the Coin. Cancers 2021, 13, 2733. [CrossRef]

82. Hu, L.; Cui, R.; Liu, H.; Wang, F. Emodin and rhein decrease levels of hypoxia-inducible factor- $1 \alpha$ in human pancreatic cancer cells and attenuate cancer cachexia in athymic mice carrying these cells. Oncotarget 2017, 8, 88008-88020. [CrossRef] [PubMed]

83. Rabinovitch, R.C.; Samborska, B.; Faubert, B.; Ma, E.H.; Gravel, S.-P.; Andrzejewski, S.; Raissi, T.C.; Pause, A.; St.-Pierre, J.; Jones, R.G. AMPK Maintains Cellular Metabolic Homeostasis through Regulation of Mitochondrial Reactive Oxygen Species. Cell Rep. 2017, 21, 1-9. [CrossRef] [PubMed]

84. Gao, Y.-H.; Li, C.-X.; Shen, S.-M.; Li, H.; Chen, G.-Q.; Wei, Q.; Wang, L.-S. Hypoxia-inducible factor $1 \alpha$ mediates the downregulation of superoxide dismutase 2 in von Hippel-Lindau deficient renal clear cell carcinoma. Biochem. Biophys. Res. Commun. 2013, 435, 46-51. [CrossRef] [PubMed]

85. Patergnani, S.; Missiroli, S.; Morciano, G.; Perrone, M.; Mantovani, C.M.; Anania, G.; Fiorica, F.; Pinton, P.; Giorgi, C. Understanding the Role of Autophagy in Cancer Formation and Progression Is a Real Opportunity to Treat and Cure Human Cancers. Cancers 2021, 13, 5622. [CrossRef]

86. Patergnani, S.; Bonora, M.; Ingusci, S.; Previati, M.; Marchi, S.; Zucchini, S.; Perrone, M.; Wieckowski, M.R.; Castellazzi, M.; Pugliatti, M.; et al. Antipsychotic drugs counteract autophagy and mitophagy in multiple sclerosis. Proc. Natl. Acad. Sci. 2021, 118, 2020078118. [CrossRef] [PubMed]

87. Song, M.; Franco, A.; Fleischer, J.A.; Zhang, L.; Dorn, G.W. Abrogating Mitochondrial Dynamics in Mouse Hearts Accelerates Mitochondrial Senescence. Cell Metab. 2017, 26, 872-883.e5. [CrossRef]

88. Torrano, V.; Valcarcel-Jimenez, L.; Cortazar, A.R.; Liu, X.; Urosevic, J.; Castillo-Martin, M.; Fernández-Ruiz, S.; Morciano, G.; Caro-Maldonado, A.; Guiu, M.; et al. The metabolic co-regulator PGC1 $\alpha$ suppresses prostate cancer metastasis. Nat. Cell Biol. 2016, 18, 645-656. [CrossRef] [PubMed]

89. Sebastian, D.; Hernandez-Alvarez, M.I.; Segales, J.; Sorianello, E.; Muñoz, J.P.; Sala, D.; Waget, A.; Liesa, M.; Paz, J.C.; Gopalacharyulu, P.; et al. Mitofusin 2 (Mfn2) links mitochondrial and endoplasmic reticulum function with insulin signaling and is essential for normal glucose homeostasis. Proc. Natl. Acad. Sci. 2012, 109, 5523-5528. [CrossRef]

90. Kim, H.; Scimia, M.C.; Wilkinson, D.; Trelles, R.D.; Wood, M.R.; Bowtell, D.; Dillin, A.; Mercola, M.; Ronai, Z.A. Fine-Tuning of Drp1/Fis1 Availability by AKAP121/Siah2 Regulates Mitochondrial Adaptation to Hypoxia. Mol. Cell 2011, $44,532-544$. [CrossRef] [PubMed]

91. LeBleu, V.S.; O'Connell, J.T.; Gonzalez Herrera, K.N.G.; Wikman, H.; Pantel, K.; Haigis, M.C.; De Carvalho, F.M.; Damascena, A.; Domingos Chinen, L.T.; Rocha, R.M.; et al. PGC-1 $\alpha$ mediates mitochondrial biogenesis and oxidative phosphorylation in cancer cells to promote metastasis. Nat. Cell Biol. 2014, 16, 992-1003. [CrossRef] [PubMed]

92. Palikaras, K.; Lionaki, E.; Tavernarakis, N. Balancing mitochondrial biogenesis and mitophagy to maintain energy metabolism homeostasis. Cell Death Differ. 2015, 22, 1399-1401. [CrossRef] [PubMed]

93. Youle, R.J.; Narendra, D.P. Mechanisms of mitophagy. Nat. Rev. Mol. Cell Biol. 2011, 12, 9-14. [CrossRef] [PubMed]

94. Bellot, G.; Garcia-Medina, R.; Gounon, P.; Chiche, J.; Roux, D.; Pouysségur, J.; Mazure, N.M. Hypoxia-Induced Autophagy Is Mediated through Hypoxia-Inducible Factor Induction of BNIP3 and BNIP3L via Their BH3 Domains. Mol. Cell. Biol. 2009, 29, 2570-2581. [CrossRef] [PubMed]

95. Sowter, H.M.; Ratcliffe, P.J.; Watson, P.; Greenberg, A.H.; Harris, A.L. HIF-1-dependent regulation of hypoxic induction of the cell death factors BNIP3 and NIX in human tumors. Cancer Res. 2001, 61, 6669-6673.

96. Liu, L.; Feng, D.; Chen, G.; Chen, M.; Zheng, Q.; Song, P.; Ma, Q.; Zhu, C.; Wang, R.; Qi, W.; et al. Mitochondrial outer-membrane protein FUNDC1 mediates hypoxia-induced mitophagy in mammalian cells. Nat. Cell Biol. 2014, 14, 177-185. [CrossRef]

97. Araki, K.; Kawauchi, K.; Sugimoto, W.; Tsuda, D.; Oda, H.; Yoshida, R.; Ohtani, K. Mitochondrial protein E2F3d, a distinctive E2F3 product, mediates hypoxia-induced mitophagy in cancer cells. Commun. Biol. 2019, 2, 3. [CrossRef]

98. Di Meo, S.; Reed, T.T.; Venditti, P.; Victor, V.M. Role of ROS and RNS Sources in Physiological and Pathological Conditions. Oxid. Med. Cell. Longev. 2016, 2016, 1245049. [CrossRef]

99. Dikalov, S.I.; Nazarewicz, R.R. Angiotensin II-Induced Production of Mitochondrial Reactive Oxygen Species: Potential Mechanisms and Relevance for Cardiovascular Disease. Antioxid. Redox Signal. 2013, 19, 1085-1094. [CrossRef]

100. Münzel, T.; Camici, G.G.; Maack, C.; Bonetti, N.R.; Fuster, V.; Kovacic, J.C. Impact of Oxidative Stress on the Heart and Vasculature. J. Am. Coll. Cardiol. 2017, 70, 212-229. [CrossRef] 
101. Lenaz, G. The Mitochondrial Production of Reactive Oxygen Species: Mechanisms and Implications in Human Pathology. IUBMB Life 2001, 52, 159-164. [CrossRef] [PubMed]

102. Lambertucci, R.H.; Hirabara, S.M.; Silveira, L.D.R.; Levada-Pires, A.C.; Curi, R.; Pithon-Curi, T.C. Palmitate increases superoxide production through mitochondrial electron transport chain and NADPH oxidase activity in skeletal muscle cells. J. Cell. Physiol. 2008, 216, 796-804. [CrossRef]

103. Di Lisa, F.; Kaludercic, N.; Carpi, A.; Menabò, R.; Giorgio, M. Mitochondrial pathways for ROS formation and myocardial injury: The relevance of p66Shc and monoamine oxidase. Basic Res. Cardiol. 2009, 104, 131-139. [CrossRef]

104. Starkov, A.; Fiskum, G.; Chinopoulos, C.; Lorenzo, B.J.; Browne, S.E.; Patel, M.S.; Beal, M.F. Mitochondrial -Ketoglutarate Dehydrogenase Complex Generates Reactive Oxygen Species. J. Neurosci. 2004, 24, 7779-7788. [CrossRef]

105. St-Pierre, J.; Buckingham, J.A.; Roebuck, S.J.; Brand, M. Topology of Superoxide Production from Different Sites in the Mitochondrial Electron Transport Chain. J. Biol. Chem. 2002, 277, 44784-44790. [CrossRef]

106. Vásquez-Vivar, J.; Kalyanaraman, B.; Kennedy, M.C. Mitochondrial Aconitase Is a Source of Hydroxyl Radical. J. Biol. Chem. 2000, 275, 14064-14069. [CrossRef] [PubMed]

107. Weyemi, U.; Dupuy, C. The emerging role of ROS-generating NADPH oxidase NOX4 in DNA-damage responses. Mutat. Res. Mutat. Res. 2012, 751,77-81. [CrossRef]

108. Giorgio, M.; Migliaccio, E.; Orsini, F.; Paolucci, D.; Moroni, M.; Contursi, C.; Pelliccia, G.; Luzi, L.; Minucci, S.; Marcaccio, M.; et al. Electron Transfer between Cytochrome c and p66Shc Generates Reactive Oxygen Species that Trigger Mitochondrial Apoptosis. Cell 2005, 122, 221-233. [CrossRef]

109. Giorgi, C.; Marchi, S.; Simoes, I.C.; Ren, Z.; Morciano, G.; Perrone, M.; Patalas-Krawczyk, P.; Borchard, S.; Jędrak, P.; Pierzynowska, K.; et al. Mitochondria and Reactive Oxygen Species in Aging and Age-Related Diseases. Int. Rev. Cell Mol. Biol. 2018, 340, 209-344. [CrossRef] [PubMed]

110. Arnaiz, S.L.; Coronel, M.F.; Boveris, A. Nitric Oxide, Superoxide, and Hydrogen Peroxide Production in Brain Mitochondria after Haloperidol Treatment. Nitric Oxide 1999, 3, 235-243. [CrossRef]

111. Tewari, S.; Santos, J.M.; Kowluru, R.A. Damaged Mitochondrial DNA Replication System and the Development of Diabetic Retinopathy. Antioxid. Redox Signal. 2012, 17, 492-504. [CrossRef] [PubMed]

112. Tewari, S.; Zhong, Q.; Santos, J.M.; A Kowluru, R. Mitochondria DNA Replication and DNA Methylation in the Metabolic Memory Associated with Continued Progression of Diabetic Retinopathy. Investig. Ophthalmol. Vis. Sci. 2012, 53, 4881-4888. [CrossRef]

113. Morciano, G.; Naumova, N.; Koprowski, P.; Valente, S.; Sardão, V.A.; Potes, Y.; Rimessi, A.; Wieckowski, M.R.; Oliveira, P.J. The mitochondrial permeability transition pore: An evolving concept critical for cell life and death. Biol. Rev. 2021, 96, 2489-2521. [CrossRef]

114. Radi, R.; Turrens, J.; Chang, L.; Bush, K.; Crapo, J.; Freeman, B. Detection of catalase in rat heart mitochondria. J. Biol. Chem. 1991, 266, 22028-22034. [CrossRef]

115. Zhou, R.; Yazdi, A.S.; Menu, P.; Tschopp, J. A role for mitochondria in NLRP3 inflammasome activation. Nature 2011, 469, 221-225. [CrossRef]

116. Zorov, D.B.; Juhaszova, M.; Sollott, S.J. Mitochondrial Reactive Oxygen Species (ROS) and ROS-Induced ROS Release. Physiol. Rev. 2014, 94, 909-950. [CrossRef]

117. Patergnani, S.; Bouhamida, E.; Leo, S.; Pinton, P.; Rimessi, A. Mitochondrial Oxidative Stress and "Mito-Inflammation": Actors in the Diseases. Biomedicines 2021, 9, 216. [CrossRef]

118. Bonora, M.; Wieckowski, M.; Sinclair, D.; Kroemer, G.; Pinton, P.; Galluzzi, L. Targeting mitochondria for cardiovascular disorders: Therapeutic potential and obstacles. Nat. Rev. Cardiol. 2019, 16, 33-55. [CrossRef]

119. Bonora, M.; Pinton, P. A New Current for the Mitochondrial Permeability Transition. Trends Biochem. Sci. 2019, 44, 559-561. [CrossRef] [PubMed]

120. Zhong, Z.; Liang, S.; Sanchez-Lopez, E.; He, F.; Shalapour, S.; Lin, X.-J.; Wong, J.; Ding, S.; Seki, E.; Schnabl, B.; et al. New mitochondrial DNA synthesis enables NLRP3 inflammasome activation. Nature 2018, 560, 198-203. [CrossRef] [PubMed]

121. Idzko, M.; Hammad, H.; Van Nimwegen, M.; Kool, M.; Willart, M.A.M.; Muskens, F.; Hoogsteden, H.C.; Luttmann, W.; Ferrari, D.; Di Virgilio, F.; et al. Extracellular ATP triggers and maintains asthmatic airway inflammation by activating dendritic cells. Nat. Med. 2007, 13, 913-919. [CrossRef] [PubMed]

122. Wang, P.; Chaung, W.W.; Wu, R.; Ji, Y.; Dong, W. Mitochondrial transcription factor A is a proinflammatory mediator in hemorrhagic shock. Int. J. Mol. Med. 2012, 30, 199-203. [CrossRef] [PubMed]

123. Zhang, Q.; Raoof, M.; Chen, Y.; Sumi, Y.; Sursal, T.; Junger, W.; Brohi, K.; Itagaki, K.; Hauser, C.J. Circulating mitochondrial DAMPs cause inflammatory responses to injury. Nature 2010, 464, 104-107. [CrossRef] [PubMed]

124. Nakahira, K.; Hisata, S.; Choi, A.M. The Roles of Mitochondrial Damage-Associated Molecular Patterns in Diseases. Antioxid. Redox Signal. 2015, 23, 1329-1350. [CrossRef] [PubMed]

125. Tuominen, A.; Miller, Y.I.; Hansen, L.F.; Kesäniemi, Y.A.; Witztum, J.L.; Hörkkö, S. A Natural Antibody to Oxidized Cardiolipin Binds to Oxidized Low-Density Lipoprotein, Apoptotic Cells, and Atherosclerotic Lesions. Arter. Thromb. Vasc. Biol. 2006, 26, 2096-2102. [CrossRef] [PubMed] 
126. Misawa, T.; Takahama, M.; Kozaki, T.; Lee, H.; Zou, J.; Saitoh, T.; Akira, S. Microtubule-driven spatial arrangement of mitochondria promotes activation of the NLRP3 inflammasome. Nat. Immunol. 2013, 14, 454-460. [CrossRef]

127. Senoner, T.; Dichtl, W. Oxidative Stress in Cardiovascular Diseases: Still a Therapeutic Target? Nutrients 2019, 11, 2090. [CrossRef]

128. Morciano, G.; Vitto, V.; Bouhamida, E.; Giorgi, C.; Pinton, P. Mitochondrial Bioenergetics and Dynamism in the Failing Heart. Life 2021, 11, 436. [CrossRef]

129. Parathath, S.; Mick, S.L.; Feig, J.E.; Joaquin, V.; Grauer, L.; Habiel, D.M.; Gassmann, M.; Gardner, L.; Fisher, E.A. Hypoxia Is Present in Murine Atherosclerotic Plaques and Has Multiple Adverse Effects on Macrophage Lipid Metabolism. Circ. Res. 2011, 109, 1141-1152. [CrossRef]

130. Jin, Y.; Fu, J. Novel Insights Into the NLRP3 Inflammasome in Atherosclerosis. J. Am. Hear. Assoc. 2019, 8, e012219. [CrossRef]

131. Proudfoot, D.; Skepper, J.N.; Hegyi, L.; Bennett, M.R.; Shanahan, C.; Weissberg, P.L. Apoptosis Regulates Human Vascular Calcification In Vitro. Circ. Res. 2000, 87, 1055-1062. [CrossRef] [PubMed]

132. Hutcheson, J.D.; Goettsch, C.; Bertazzo, S.; Maldonado, N.; Ruiz, J.L.; Bin Goh, W.W.; Yabusaki, K.; Faits, T.; Bouten, C.; Franck, G.; et al. Genesis and growth of extracellular-vesicle-derived microcalcification in atherosclerotic plaques. Nat. Mater. 2016, 15, 335-343. [CrossRef] [PubMed]

133. Harrison, C.M.; Pompilius, M.; Pinkerton, K.E.; Ballinger, S.W. Mitochondrial Oxidative Stress Significantly Influences Atherogenic Risk and Cytokine-Induced Oxidant Production. Environ. Heal. Perspect. 2011, 119, 676-681. [CrossRef]

134. Orsini, F.; Migliaccio, E.; Moroni, M.; Contursi, C.; Raker, V.A.; Piccini, D.; Martin-Padura, I.; Pelliccia, G.; Trinei, M.; Bono, M.; et al. The Life Span Determinant p66Shc Localizes to Mitochondria Where It Associates with Mitochondrial Heat Shock Protein 70 and Regulates Trans-membrane Potential. J. Biol. Chem. 2004, 279, 25689-25695. [CrossRef]

135. Graiani, G.; Lagrasta, C.; Migliaccio, E.; Spillmann, F.; Meloni, M.; Madeddu, P.; Quaini, F.; Padura, I.M.; Lanfrancone, L.; Pelicci, P.; et al. Genetic Deletion of the p66 Shc Adaptor Protein Protects from Angiotensin II-Induced Myocardial Damage. Hypertension 2005, 46, 433-440. [CrossRef] [PubMed]

136. Rota, M.; LeCapitaine, N.; Hosoda, T.; Boni, A.; De Angelis, A.; Padin-Iruegas, M.E.; Esposito, G.; Vitale, S.; Urbanek, K.; Casarsa, C.; et al. Diabetes Promotes Cardiac Stem Cell Aging and Heart Failure, Which Are Prevented by Deletion of the p66 shc Gene. Circ. Res. 2006, 99, 42-52. [CrossRef]

137. Kaludercic, N.; Takimoto, E.; Nagayama, T.; Feng, N.; Lai, E.W.; Bedja, D.; Chen, K.; Gabrielson, K.L.; Blakely, R.D.; Shih, J.C.; et al. Monoamine Oxidase A-Mediated Enhanced Catabolism of Norepinephrine Contributes to Adverse Remodeling and Pump Failure in Hearts with Pressure Overload. Circ. Res. 2010, 106, 193-202. [CrossRef]

138. Kaludercic, N.; Carpi, A.; Nagayama, T.; Sivakumaran, V.; Zhu, G.; Lai, E.W.; Bedja, D.; De Mario, A.; Chen, K.; Gabrielson, K.L.; et al. Monoamine Oxidase B Prompts Mitochondrial and Cardiac Dysfunction in Pressure Overloaded Hearts. Antioxid. Redox Signal. 2014, 20, 267-280. [CrossRef]

139. Kuroda, J.; Ago, T.; Matsushima, S.; Zhai, P.; Schneider, M.; Sadoshima, J. NADPH oxidase 4 (Nox4) is a major source of oxidative stress in the failing heart. Proc. Natl. Acad. Sci. 2010, 107, 15565-15570. [CrossRef]

140. Ikegami, T.; Suzuki, Y.-I.; Shimizu, T.; Isono, K.; Koseki, H.; Shirasawa, T. Model mice for tissue-specific deletion of the manganese superoxide dismutase (MnSOD) gene. Biochem. Biophys. Res. Commun. 2002, 296, 729-736. [CrossRef]

141. Sharma, S.; Bhattarai, S.; Ara, H.; Sun, G.; Clair, D.K.S.; Bhuiyan, S.; Kevil, C.; Watts, M.N.; Dominic, P.; Shimizu, T.; et al. SOD2 deficiency in cardiomyocytes defines defective mitochondrial bioenergetics as a cause of lethal dilated cardiomyopathy. Redox Biol. 2020, 37, 101740. [CrossRef] [PubMed]

142. Souiden, Y.; Mallouli, H.; Meskhi, S.; Chaabouni, Y.; Rebai, A.; Chéour, F.; Mahdouani, K. MnSOD and GPx1 polymorphism relationship with coronary heart disease risk and severity. Biol. Res. 2016, 49, 22. [CrossRef]

143. Faraci, F.M.; Didion, S.P. Vascular Protection. Arter. Thromb. Vasc. Biol. 2004, 24, 1367-1373. [CrossRef] [PubMed]

144. Ardanaz, N.; Yang, X.-P.; Cifuentes, M.E.; Haurani, M.J.; Jackson, K.W.; Liao, T.-D.; Carretero, O.A.; Pagano, P.J. Lack of Glutathione Peroxidase 1 Accelerates Cardiac-Specific Hypertrophy and Dysfunction in Angiotensin II Hypertension. Hypertension 2010, 55, 116-123. [CrossRef] [PubMed]

145. Chen, Z.; Chua, C.C.; Gao, J.; Chua, K.-W.; Ho, Y.-S.; Hamdy, R.C.; Chua, B.H.L. Prevention of ischemia/reperfusion-induced cardiac apoptosis and injury by melatonin is independent of glutathione peroxdiase 1. J. Pineal Res. 2009, 46, 235-241. [CrossRef]

146. Matsushima, S.; Ide, T.; Yamato, M.; Matsusaka, H.; Hattori, F.; Ikeuchi, M.; Kubota, T.; Sunagawa, K.; Hasegawa, Y.; Kurihara, T.; et al. Overexpression of Mitochondrial Peroxiredoxin-3 Prevents Left Ventricular Remodeling and Failure After Myocardial Infarction in Mice. Circulation 2006, 113, 1779-1786. [CrossRef] [PubMed]

147. Huang, Q.; Zhou, H.J.; Zhang, H.; Huang, Y.; Hinojosa-Kirschenbaum, F.; Fan, P.; Yao, L.; Belardinelli, L.; Tellides, G.; Giordano, F.J.; et al. Thioredoxin-2 Inhibits Mitochondrial Reactive Oxygen Species Generation and Apoptosis Stress Kinase-1 Activity to Maintain Cardiac Function. Circulation 2015, 131, 1082-1097. [CrossRef]

148. Flores-Mateo, G.; Carrillo-Santisteve, P.; Elosua, R.; Guallar, E.; Marrugat, J.; Bleys, J.; Covas, M.-I. Antioxidant Enzyme Activity and Coronary Heart Disease: Meta-analyses of Observational Studies. Am. J. Epidemiol. 2009, 170, 135-147. [CrossRef]

149. Tonet, E.; Bernucci, D.; Morciano, G.; Campo, G. Pharmacological protection of reperfusion injury in ST-segment elevation myocardial infarction. Gone with the wind? Postepy Kardiol Interwencyjnej 2018, 14, 5-8. [CrossRef]

150. Calbet, J.A. Chronic hypoxia increases blood pressure and noradrenaline spillover in healthy humans. J. Physiol. 2003, 551, 379-386. [CrossRef] 
151. Lee, S.H.; Wolf, P.L.; Escudero, R.; Deutsch, R.; Jamieson, S.W.; Thistlethwaite, P.A. Early Expression of Angiogenesis Factors in Acute Myocardial Ischemia and Infarction. New Engl. J. Med. 2000, 342, 626-633. [CrossRef] [PubMed]

152. Liu, Y.; Luo, Q.; Su, Z.; Xing, J.; Wu, J.; Xiang, L.; Huang, Y.; Pan, H.; Wu, X.; Zhang, X.; et al. Suppression of Myocardial Hypoxia-Inducible Factor- $1 \alpha$ Compromises Metabolic Adaptation and Impairs Cardiac Function in Patients with Cyanotic Congenital Heart Disease During Puberty. Circulation 2021, 143, 2254-2272. [CrossRef]

153. Murry, C.E.; Jennings, R.B.; Reimer, K.A. Preconditioning with ischemia: A delay of lethal cell injury in ischemic myocardium. Circulation 1986, 74, 1124-1136. [CrossRef]

154. Morciano, G.; Giorgi, C.; Bonora, M.; Punzetti, S.; Pavasini, R.; Wieckowski, M.; Campo, G.; Pinton, P. Molecular identity of the mitochondrial permeability transition pore and its role in ischemia-reperfusion injury. J. Mol. Cell. Cardiol. 2015, 78, 142-153. [CrossRef]

155. Giorgi, C.; Marchi, S.; Pinton, P. The machineries, regulation and cellular functions of mitochondrial calcium. Nat. Rev. Mol. Cell Biol. 2018, 19, 713-730. [CrossRef]

156. Bonora, M.; Giorgi, C.; Pinton, P. Molecular mechanisms and consequences of mitochondrial permeability transition. Nat. Rev. Mol. Cell Biol. 2021, 1-20. [CrossRef] [PubMed]

157. Modesti, L.; Danese, A.; Vitto, V.A.M.; Ramaccini, D.; Aguiari, G.; Gafà, R.; Lanza, G.; Giorgi, C.; Pinton, P. Mitochondrial Ca ${ }^{2+}$ Signaling in Health, Disease and Therapy. Cells 2021, 10, 1317. [CrossRef] [PubMed]

158. Luongo, T.; Lambert, J.; Yuan, A.; Zhang, X.; Gross, P.; Song, J.; Shanmughapriya, S.; Gao, E.; Jain, M.; Houser, S.R.; et al. The Mitochondrial Calcium Uniporter Matches Energetic Supply with Cardiac Workload during Stress and Modulates Permeability Transition. Cell Rep. 2015, 12, 23-34. [CrossRef]

159. Kwong, J.Q.; Lu, X.; Correll, R.N.; Schwanekamp, J.; Vagnozzi, R.J.; Sargent, M.A.; York, A.J.; Zhang, J.; Bers, D.; Molkentin, J.D The Mitochondrial Calcium Uniporter Selectively Matches Metabolic Output to Acute Contractile Stress in the Heart. Cell Rep. 2015, 12, 15-22. [CrossRef]

160. Chouchani, E.T.; Pell, V.R.; Gaude, E.; Aksentijevic, D.; Sundier, S.Y.; Robb, E.L.; Logan, A.; Nadtochiy, S.M.; Ord, E.N.J.; Smith, A.C.; et al. Ischaemic accumulation of succinate controls reperfusion injury through mitochondrial ROS. Nature 2014, 515, 431-435. [CrossRef]

161. Jang, S.; Lewis, T.S.; Powers, C.; Khuchua, Z.; Baines, C.P.; Wipf, P.; Javadov, S. Elucidating Mitochondrial Electron Transport Chain Supercomplexes in the Heart During Ischemia-Reperfusion. Antioxid. Redox Signal. 2017, 27, 57-69. [CrossRef] [PubMed]

162. Mezzaroma, E.; Toldo, S.; Farkas, D.; Seropian, I.M.; Van Tassell, B.W.; Salloum, F.; Kannan, H.R.; Menna, A.C.; Voelkel, N.F.; Abbate, A. The inflammasome promotes adverse cardiac remodeling following acute myocardial infarction in the mouse. Proc. Natl. Acad. Sci. 2011, 108, 19725-19730. [CrossRef] [PubMed]

163. Sandanger, Ø.; Ranheim, T.; Vinge, L.E.; Bliksøen, M.; Alfsnes, K.; Finsen, A.V.; Dahl, C.P.; Askevold, E.T.; Florholmen, G.; Christensen, G.; et al. The NLRP3 inflammasome is up-regulated in cardiac fibroblasts and mediates myocardial ischaemiareperfusion injury. Cardiovasc. Res. 2013, 99, 164-174. [CrossRef] [PubMed]

164. Malhotra, R.; Tyson, D.W.; Rosevear, H.M.; Brosius, F.C. Hypoxia-inducible factor-1alpha is a critical mediator of hypoxia induced apoptosis in cardiac H9c2 and kidney epithelial HK-2 cells. BMC Cardiovasc. Disord. 2008, 8, 9. [CrossRef]

165. Moslehi, J.; Minamishima, Y.A.; Shi, J.; Neuberg, D.; Charytan, D.; Padera, R.F.; Signoretti, S.; Liao, R.; Kaelin, W.G. Loss of Hypoxia-Inducible Factor Prolyl Hydroxylase Activity in Cardiomyocytes Phenocopies Ischemic Cardiomyopathy. Circulation 2010, 122, 1004-1016. [CrossRef]

166. Loor, G.; Schumacker, P.T. Role of hypoxia-inducible factor in cell survival during myocardial ischemia-reperfusion. Cell Death Differ. 2008, 15, 686-690. [CrossRef] [PubMed]

167. Li, B.; Li, M.; Li, X.; Li, H.; Lai, Y.; Huang, S.; He, X.; Si, X.; Zheng, H.; Liao, W.; et al. Sirt1-inducible deacetylation of p21 promotes cardiomyocyte proliferation. Aging 2019, 11, 12546-12567. [CrossRef] [PubMed]

168. Luo, G.; Jian, Z.; Zhu, Y.; Chen, B.; Ma, R.; Tang, F.; Xiao, Y. Sirt1 promotes autophagy and inhibits apoptosis to protect cardiomyocytes from hypoxic stress. Int. J. Mol. Med. 2019, 43, 2033-2043. [CrossRef]

169. Robador, P.A.; José, G.S.; Rodríguez, C.; Guadall, A.; Moreno, M.U.; Beaumont, J.; Fortuño, A.; Díez, J.; Martínez-González, J.; Zalba, G. HIF-1-mediated up-regulation of cardiotrophin-1 is involved in the survival response of cardiomyocytes to hypoxia. Cardiovasc. Res. 2011, 92, 247-255. [CrossRef]

170. Tennant, D.; Howell, N.J. The role of HIFs in ischemia-reperfusion injury. Hypoxia 2014, 2, 107-115. [CrossRef]

171. Wan, D.-Y.; Zhang, Z.; Yang, H.-H. Cardioprotective effect of miR-214 in myocardial ischemic postconditioning by downregulation of hypoxia inducible factor 1, alpha subunit inhibitor. Cell. Mol. Biol. 2015, 61, 1-6.

172. Stanley, M.; Crowcroft, N.; Quigley, J.; Parkinson, E. Responses of human cervical keratinocytes in vitro to tumour promoters and diethylstilboestrol. Carcinogenesis 1985, 6, 1011-1015. [CrossRef] [PubMed]

173. Chaudhuri, R.D.; Banik, A.; Mandal, B.; Sarkar, S. Cardiac-specific overexpression of HIF-1 $\alpha$ during acute myocardial infarction ameliorates cardiomyocyte apoptosis via differential regulation of hypoxia-inducible pro-apoptotic and anti-oxidative genes. Biochem. Biophys. Res. Commun. 2021, 537, 100-108. [CrossRef]

174. Yang, B.; He, K.; Zheng, F.; Wan, L.; Yu, X.; Wang, X.; Zhao, D.; Bai, Y.; Chu, W.; Sun, Y.; et al. Over-expression of hypoxia-inducible factor-1 alpha in vitro protects the cardiac fibroblasts from hypoxia-induced apoptosis. J. Cardiovasc. Med. 2014, 15, 579-586. [CrossRef] 
175. Zhu, H.; Sun, A. Programmed necrosis in heart disease: Molecular mechanisms and clinical implications. J. Mol. Cell. Cardiol. 2018, 116, 125-134. [CrossRef]

176. Piamsiri, C.; Maneechote, C.; Siri-Angkul, N.; Chattipakorn, S.C.; Chattipakorn, N. Targeting necroptosis as therapeutic potential in chronic myocardial infarction. J. Biomed. Sci. 2021, 28, 1-13. [CrossRef]

177. Karunakaran, D.; Geoffrion, M.; Wei, L.; Gan, W.; Richards, L.; Shangari, P.; DeKemp, E.M.; Beanlands, R.A.; Perisic, L.; Maegdefessel, L.; et al. Targeting macrophage necroptosis for therapeutic and diagnostic interventions in atherosclerosis. Sci. Adv. 2016, 2, e1600224. [CrossRef]

178. Zhang, T.; Zhang, Y.; Cui, M.; Jin, L.; Wang, Y.; Lv, F.; Liu, Y.; Zheng, W.; Shang, H.; Zhang, J.; et al. CaMKII is a RIP3 substrate mediating ischemia- and oxidative stress-induced myocardial necroptosis. Nat. Med. 2016, 22, 175-182. [CrossRef] [PubMed]

179. Karshovska, E.; Wei, Y.; Subramanian, P.; Mohibullah, R.; Geißler, C.; Baatsch, I.; Popal, A.; Campos, J.C.; Exner, N.; Schober, A. HIF- $1 \alpha$ (Hypoxia-Inducible Factor-1 $\alpha$ ) Promotes Macrophage Necroptosis by Regulating miR-210 and miR-383. Arter. Thromb. Vasc. Biol. 2020, 40, 583-596. [CrossRef] [PubMed]

180. Liu, B.; Zhao, C.; Li, H.; Chen, X.; Ding, Y.; Xu, S. Puerarin protects against heart failure induced by pressure overload through mitigation of ferroptosis. Biochem. Biophys. Res. Commun. 2018, 497, 233-240. [CrossRef]

181. Chen, X.; Xu, S.; Zhao, C.; Liu, B. Role of TLR4/NADPH oxidase 4 pathway in promoting cell death through autophagy and ferroptosis during heart failure. Biochem. Biophys. Res. Commun. 2019, 516, 37-43. [CrossRef]

182. Yoshimura, C.; Nagasaka, A.; Kurose, H.; Nakaya, M. Efferocytosis during myocardial infarction. J. Biochem. $2020,168,1-6$. [CrossRef]

183. Davis, C.K.; Jain, S.A.; Bae, O.-N.; Majid, A.; Rajanikant, G.K. Hypoxia Mimetic Agents for Ischemic Stroke. Front. Cell Dev. Biol. 2019, 6, 175. [CrossRef]

184. Yu, Y.; Yan, Y.; Niu, F.; Wang, Y.; Chen, X.; Su, G.; Liu, Y.; Zhao, X.; Qian, L.; Liu, P.; et al. Ferroptosis: A cell death connecting oxidative stress, inflammation and cardiovascular diseases. Cell Death Discov. 2021, 7, 1-10. [CrossRef] [PubMed]

185. Li, W.; Li, W.; Leng, Y.; Xiong, Y.; Xia, Z. Ferroptosis Is Involved in Diabetes Myocardial Ischemia/Reperfusion Injury Through Endoplasmic Reticulum Stress. DNA Cell Biol. 2020, 39, 210-225. [CrossRef]

186. Gao, M.; Monian, P.; Quadri, N.; Ramasamy, R.; Jiang, X. Glutaminolysis and Transferrin Regulate Ferroptosis. Mol. Cell 2015, 59, 298-308. [CrossRef] [PubMed]

187. Tang, L.-J.; Luo, X.-J.; Tu, H.; Chen, H.; Xiong, X.-M.; Li, N.-S.; Peng, J. Ferroptosis occurs in phase of reperfusion but not ischemia in rat heart following ischemia or ischemia/reperfusion. Naunyn-Schmiedebergs Arch. fur Exp. Pathol. Pharmakol. 2021, 394, 401-410. [CrossRef] [PubMed]

188. Tay, W.T.; Fang, Y.-H.; Beh, S.T.; Liu, Y.-W.; Hsu, L.-W.; Yen, C.-J.; Liu, P.-Y. Programmed Cell Death-1: Programmed Cell Death-Ligand 1 Interaction Protects Human Cardiomyocytes Against T-Cell Mediated Inflammation and Apoptosis Response In Vitro. Int. J. Mol. Sci. 2020, 21, 2399. [CrossRef]

189. Van der Windt, G.J.W.; O'Sullivan, D.; Everts, B.; Huang, S.C.-C.; Buck, M.; Curtis, J.D.; Chang, C.-H.; Smith, A.M.; Ai, T.; Faubert, B.; et al. CD8 memory T cells have a bioenergetic advantage that underlies their rapid recall ability. Proc. Natl. Acad. Sci. USA 2013, 110, 14336-14341. [CrossRef]

190. Wang, R.; Dillon, C.P.; Shi, L.Z.; Milasta, S.; Carter, R.; Finkelstein, D.; McCormick, L.L.; Fitzgerald, P.; Chi, H.; Munger, J.; et al. The Transcription Factor Myc Controls Metabolic Reprogramming upon T Lymphocyte Activation. Immunity 2011, 35, 871-882. [CrossRef]

191. Gao, P.; Tchernyshyov, I.; Chang, T.-C.; Lee, Y.-S.; Kita, K.; Ochi, T.; Zeller, K.I.; De Marzo, A.M.; Van Eyk, J.E.; Mendell, J.T.; et al. c-Myc suppression of miR-23a/b enhances mitochondrial glutaminase expression and glutamine metabolism. Nature 2009, 458, 762-765. [CrossRef] [PubMed]

192. Shi, L.Z.; Wang, R.; Huang, G.; Vogel, P.; Neale, G.; Green, D.R.; Chi, H. HIF1 $\alpha$-dependent glycolytic pathway orchestrates a metabolic checkpoint for the differentiation of TH17 and Treg cells. J. Exp. Med. 2011, 208, 1367-1376. [CrossRef] [PubMed]

193. Finlay, D.K.; Rosenzweig, E.; Sinclair, L.V.; Carmen, F.C.; Hukelmann, J.L.; Rolf, J.; Panteleyev, A.A.; Okkenhaug, K.; Cantrell, D.A PDK1 regulation of mTOR and hypoxia-inducible factor 1 integrate metabolism and migration of CD8+ T cells. J. Exp. Med. 2012, 209, 2441-2453. [CrossRef] [PubMed]

194. Gualdoni, G.A.; Mayer, K.A.; Göschl, L.; Boucheron, N.; Ellmeier, W.; Zlabinger, G.J. The AMP analog AICAR modulates the T reg / T h 17 axis through enhancement of fatty acid oxidation. FASEB J. 2016, 30, 3800-3809. [CrossRef]

195. Sun, Y.; Tian, T.; Gao, J.; Liu, X.; Hou, H.; Cao, R.; Li, B.; Quan, M.; Guo, L. Metformin ameliorates the development of experimental autoimmune encephalomyelitis by regulating T helper 17 and regulatory T cells in mice. J. Neuroimmunol. 2016, $292,58-67$. [CrossRef]

196. Rolf, J.; Zarrouk, M.; Finlay, D.K.; Foretz, M.; Viollet, B.; Cantrell, D.A. AMPK $\alpha 1$ : A glucose sensor that controls CD8 T-cell memory. Eur. J. Immunol. 2013, 43, 889-896. [CrossRef]

197. Pearce, E.L.; Walsh, M.C.; Cejas, P.J.; Harms, G.M.; Shen, H.; Wang, L.-S.; Jones, R.G.; Choi, Y. Enhancing CD8 T-cell memory by modulating fatty acid metabolism. Nature 2009, 460, 103-107. [CrossRef]

198. Putignani, L.; Raffa, S.; Pescosolido, R.; Aimati, L.; Signore, F.; Torrisi, M.R.; Grammatico, P. Alteration of expression levels of the oxidative phosphorylation system (OXPHOS) in breast cancer cell mitochondria. Breast Cancer Res. Treat. 2007, 110, 439-452. [CrossRef] 
199. Simonnet, H.; Alazard, N.; Pfeiffer, K.; Gallou, C.; Beroud, C.; Demont, J.; Bouvier, R.; Schägger, H.; Godinot, C. Low mitochondrial respiratory chain content correlates with tumor aggressiveness in renal cell carcinoma. Carcinog. 2002, 23, 759-768. [CrossRef]

200. Bonora, E.; Porcelli, A.M.; Gasparre, G.; Biondi, A.; Ghelli, A.; Carelli, V.; Baracca, A.; Tallini, G.; Martinuzzi, A.; Lenaz, G.; et al. Defective Oxidative Phosphorylation in Thyroid Oncocytic Carcinoma Is Associated with Pathogenic Mitochondrial DNA Mutations Affecting Complexes I and III. Cancer Res. 2006, 66, 6087-6096. [CrossRef]

201. Robles, A.I.; Traverso, G.; Zhang, M.; Roberts, N.J.; Khan, M.A.; Joseph, C.; Lauwers, G.Y.; Selaru, F.M.; Popoli, M.; Pittman, M.E.; et al. Whole-Exome Sequencing Analyses of Inflammatory Bowel Disease-Associated Colorectal Cancers. Gastroenterology 2016, 150, 931-943. [CrossRef] [PubMed]

202. Dmitrieva-Posocco, O.; Dzutsev, A.; Posocco, D.F.; Hou, V.; Yuan, W.; Thovarai, V.; Mufazalov, I.; Gunzer, M.; Shilovskiy, I.; Khaitov, M.; et al. Cell-Type-Specific Responses to Interleukin-1 Control Microbial Invasion and Tumor-Elicited Inflammation in Colorectal Cancer. Immunity 2019, 50, 166-180. [CrossRef] [PubMed]

203. Grivennikov, S.; Karin, E.; Terzic, J.; Mucida, D.; Yu, G.-Y.; Vallabhapurapu, S.; Scheller, J.; Rose-John, S.; Cheroutre, H.; Eckmann, L.; et al. IL-6 and Stat3 Are Required for Survival of Intestinal Epithelial Cells and Development of Colitis-Associated Cancer. Cancer Cell 2009, 15, 103-113. [CrossRef] [PubMed]

204. Joshi, A.U.; Minhas, P.S.; Liddelow, S.A.; Haileselassie, B.; Andreasson, K.I.; Dorn, G.W., II; Mochly-Rosen, D. Fragmented mitochondria released from microglia trigger A1 astrocytic response and propagate inflammatory neurodegeneration. Nat. Neurosci. 2019, 22, 1635-1648. [CrossRef] [PubMed]

205. Panchanathan, R.; Liu, H.; Choubey, D. Hypoxia primes human normal prostate epithelial cells and cancer cell lines for the NLRP3 and AIM2 inflammasome activation. Oncotarget 2016, 7, 28183-28194. [CrossRef] [PubMed]

206. Li, X.; Zhang, X.; Xia, J.; Zhang, L.; Chen, B.; Lian, G.; Yun, C.; Yang, J.; Yan, Y.; Wang, P.; et al. Macrophage HIF-2 $\alpha$ suppresses NLRP3 inflammasome activation and alleviates insulin resistance. Cell Rep. 2021, 36, 109607. [CrossRef]

207. Moon, J.-S.; Nakahira, K.; Chung, K.-P.; DeNicola, G.; Koo, M.J.; Pabón, M.A.; Rooney, K.T.; Yoon, J.-H.; Ryter, S.W.; Stout-Delgado, H.; et al. NOX4-dependent fatty acid oxidation promotes NLRP3 inflammasome activation in macrophages. Nat. Med. 2016, 22, 1002-1012. [CrossRef]

208. Missiroli, S.; Perrone, M.; Boncompagni, C.; Borghi, C.; Campagnaro, A.; Marchetti, F.; Anania, G.; Greco, P.; Fiorica, F.; Pinton, P.; et al. Targeting the NLRP3 Inflammasome as a New Therapeutic Option for Overcoming Cancer. Cancers 2021, 13, 2297. [CrossRef]

209. Guo, B.; Fu, S.; Zhang, J.; Liu, B.; Li, Z. Targeting inflammasome/IL-1 pathways for cancer immunotherapy. Sci. Rep. 2016, 6, 36107. [CrossRef] [PubMed]

210. Kaplanov, I.; Carmi, Y.; Kornetsky, R.; Shemesh, A.; Shurin, G.V.; Shurin, M.R.; Dinarello, C.A.; Voronov, E.; Apte, R.N. Blocking IL-1 $\beta$ reverses the immunosuppression in mouse breast cancer and synergizes with anti-PD-1 for tumor abrogation. Proc. Natl. Acad. Sci. USA 2018, 116, 1361-1369. [CrossRef]

211. Wang, Y.; Kong, H.; Zeng, X.; Liu, W.; Wang, Z.; Yan, X.; Wang, H.; Xie, W. Activation of NLRP3 inflammasome enhances the proliferation and migration of A549 lung cancer cells. Oncol. Rep. 2016, 35, 2053-2064. [CrossRef] [PubMed]

212. Okamoto, M.; Liu, W.; Luo, Y.; Tanaka, A.; Cai, X.; Norris, D.A.; Dinarello, C.A.; Fujita, M. Constitutively Active Inflammasome in Human Melanoma Cells Mediating Autoinflammation via Caspase-1 Processing and Secretion of Interleukin-1 $\beta$. J. Biol. Chem. 2010, 285, 6477-6488. [CrossRef]

213. Ahmad, I.; Muneer, K.M.; Tamimi, I.A.; Chang, M.E.; Ata, M.O.; Yusuf, N. Thymoquinone suppresses metastasis of melanoma cells by inhibition of NLRP3 inflammasome. Toxicol. Appl. Pharmacol. 2013, 270, 70-76. [CrossRef] [PubMed]

214. Zaki, H.; Vogel, P.; Body-Malapel, M.; Lamkanfi, M.; Kanneganti, T.-D. IL-18 Production Downstream of the Nlrp3 Inflammasome Confers Protection against Colorectal Tumor Formation. J. Immunol. 2010, 185, 4912-4920. [CrossRef] [PubMed]

215. Huber, S.; Gagliani, N.; Zenewicz, L.; Huber, F.J.; Bosurgi, L.; Hu, B.; Hedl, M.; Zhang, W.; O'connor, W.; Murphy, A.; et al IL-22BP is regulated by the inflammasome and modulates tumorigenesis in the intestine. Nature 2012, 491, 259-263. [CrossRef]

216. Wei, Q.; Mu, K.; Li, T.; Zhang, Y.; Yang, Z.; Jia, X.; Zhao, W.; Huai, W.; Guo, P.; Han, L. Deregulation of the NLRP3 inflammasome in hepatic parenchymal cells during liver cancer progression. Lab. Investig. 2013, 94, 52-62. [CrossRef]

217. Ayala, A.; Muñoz, M.F.; Argüelles, S. Lipid Peroxidation: Production, Metabolism, and Signaling Mechanisms of Malondialdehyde and 4-Hydroxy-2-Nonenal. Oxid. Med. Cell. Longev. 2014, 2014, 360438. [CrossRef]

218. Du, W.; Zhang, L.; Brett-Morris, A.; Aguila, B.; Kerner, J.; Hoppel, C.L.; Puchowicz, M.; Serra, D.; Herrero, L.; Rini, B.I.; et al. HIF drives lipid deposition and cancer in ccRCC via repression of fatty acid metabolism. Nat. Commun. 2017, 8, 1-12. [CrossRef]

219. Todisco, S.; Convertini, P.; Iacobazzi, V.; Infantino, V. TCA Cycle Rewiring as Emerging Metabolic Signature of Hepatocellular Carcinoma. Cancers 2019, 12, 68. [CrossRef]

220. Huang, D.; Li, T.; Li, X.; Zhang, L.; Sun, L.; He, X.; Zhong, X.; Jia, D.; Song, L.; Semenza, G.L.; et al. HIF-1-Mediated Suppression of Acyl-CoA Dehydrogenases and Fatty Acid Oxidation Is Critical for Cancer Progression. Cell Rep. 2014, 8, 1930-1942. [CrossRef]

221. Mylonis, I.; Simos, G.; Paraskeva, E. Hypoxia-Inducible Factors and the Regulation of Lipid Metabolism. Cells 2019, 8, 214. [CrossRef] [PubMed]

222. Sun, W.; Kato, H.; Kitajima, S.; Lee, K.L.; Gradin, K.; Okamoto, T.; Poellinger, L. Interaction between von Hippel-Lindau Protein and Fatty Acid Synthase Modulates Hypoxia Target Gene Expression. Sci. Rep. 2017, 7, 1-11. [CrossRef] [PubMed]

223. Han, J.S.; Lee, J.H.; Kong, J.; Ji, Y.; Kim, J.; Choe, S.S.; Kim, J.B. Hypoxia Restrains Lipid Utilization via Protein Kinase A and Adipose Triglyceride Lipase Downregulation through Hypoxia-Inducible Factor. Mol. Cell. Biol. 2019, 39. [CrossRef] [PubMed] 
224. Mylonis, I.; Sembongi, H.; Befani, C.; Liakos, P.; Siniossoglou, S.; Simos, G. Hypoxia causes triglyceride accumulation via HIF-1-mediated stimulation of lipin 1 expression. J. Cell Sci. 2012, 125, 3485-3493. [CrossRef]

225. Bensaad, K.; Favaro, E.; Lewis, C.A.; Peck, B.; Lord, S.; Collins, J.M.; Pinnick, K.E.; Wigfield, S.; Buffa, F.M.; Li, J.-L.; et al. Fatty Acid Uptake and Lipid Storage Induced by HIF-1 $\alpha$ Contribute to Cell Growth and Survival after Hypoxia-Reoxygenation. Cell Rep. 2014, 9, 349-365. [CrossRef]

226. Nejad, A.E.; Najafgholian, S.; Rostami, A.; Sistani, A.; Shojaeifar, S.; Esparvarinha, M.; Nedaeinia, R.; Javanmard, S.H.; Taherian, M.; Ahmadlou, M.; et al. The role of hypoxia in the tumor microenvironment and development of cancer stem cell: A novel approach to developing treatment. Cancer Cell Int. 2021, 21, 1-26. [CrossRef]

227. Graham, K.; Unger, E. Overcoming tumor hypoxia as a barrier to radiotherapy, chemotherapy and immunotherapy in cancer treatment. Int. J. Nanomed. 2018, 13, 6049-6058. [CrossRef]

228. Akakura, N.; Kobayashi, M.; Horiuchi, I.; Suzuki, A.; Wang, J.; Chen, J.; Niizeki, H.; Ki, K.; Hosokawa, M.; Asaka, M. Constitutive expression of hypoxia-inducible factor-1alpha renders pancreatic cancer cells resistant to apoptosis induced by hypoxia and nutrient deprivation. Cancer Res. 2001, 61, 6548-6554. [PubMed]

229. Steinbach, J.P.; Wolburg, H.; Klumpp, A.; Probst, H.; Weller, M. Hypoxia-induced cell death in human malignant glioma cells: Energy deprivation promotes decoupling of mitochondrial cytochrome $\mathrm{c}$ release from caspase processing and necrotic cell death. Cell Death Differ. 2003, 10, 823-832. [CrossRef]

230. Li, Z.; Jiang, L.; Chew, S.H.; Hirayama, T.; Sekido, Y.; Toyokuni, S. Carbonic anhydrase 9 confers resistance to ferroptosis/apoptosis in malignant mesothelioma under hypoxia. Redox Biol. 2019, 26, 101297. [CrossRef]

231. Zou, Y.; Palte, M.J.; Deik, A.A.; Li, H.; Eaton, J.K.; Wang, W.; Tseng, Y.-Y.; Deasy, R.; Kost-Alimova, M.; Dančík, V.; et al. A GPX4-dependent cancer cell state underlies the clear-cell morphology and confers sensitivity to ferroptosis. Nat. Commun. 2019, 10, 1-13. [CrossRef]

232. Nie, Q.; Hu, Y.; Yu, X.; Li, X.; Fang, X. Induction and application of ferroptosis in cancer therapy. Cancer Cell Int. 2022, $22,1-19$. [CrossRef]

233. Novelli, F.; Bononi, A.; Wang, Q.; Bai, F.; Patergnani, S.; Kricek, F.; Haglund, E.; Suarez, J.S.; Tanji, M.; Xu, R.; et al. BAP1 forms a trimer with HMGB1 and HDAC1 that modulates gene $\times$ environment interaction with asbestos. Proc. Natl. Acad. Sci. 2021, 118 . [CrossRef]

234. Zhang, Y.; Zhuang, L.; Gan, B. BAP1 suppresses tumor development by inducing ferroptosis upon SLC7A11 repression. Mol. Cell. Oncol. 2019, 6, 1536845. [CrossRef] [PubMed]

235. Bronkhorst, I.H.G.; Ly, L.V.; Jordanova, E.S.; Vrolijk, J.; Versluis, M.; Luyten, G.P.M.; Jager, M.J. Detection of M2-Macrophages in Uveal Melanoma and Relation with Survival. Investig. Ophthalmol. Vis. Sci. 2011, 52, 643-650. [CrossRef]

236. Brouwer, N.J.; Wierenga, A.P.A.; Gezgin, G.; Marinkovic, M.; Luyten, G.P.M.; Kroes, W.G.M.; Versluis, M.; Van Der Velden, P.A.; Verdijk, R.M.; Jager, M.J. Ischemia Is Related to Tumour Genetics in Uveal Melanoma. Cancers 2019, 11, 1004. [CrossRef] [PubMed]

237. Moeller, B.J.; Cao, Y.; Li, C.Y.; Dewhirst, M.W. Radiation activates HIF-1 to regulate vascular radiosensitivity in tumors: Role of reoxygenation, free radicals, and stress granules. Cancer Cell 2004, 5, 429-441. [CrossRef]

238. Zhang, H.; Wong, C.C.L.; Wei, H.; Gilkes, D.M.; Korangath, P.; Chaturvedi, P.; Schito, L.; Chen, J.; Krishnamachary, B.; Winnard, P.T.; et al. HIF-1-dependent expression of angiopoietin-like 4 and L1CAM mediates vascular metastasis of hypoxic breast cancer cells to the lungs. Oncogene 2012, 31, 1757-1770. [CrossRef]

239. Semenza, G.L. HIF-1 Inhibitors for Cancer Therapy: From Gene Expression to Drug Discovery. Curr. Pharm. Des. 2009, 15, 3839-3843. [CrossRef]

240. Fujiwara, S.; Nakagawa, K.; Harada, H.; Nagato, S.; Furukawa, K.; Teraoka, M.; Seno, T.; Oka, K.; Iwata, S.; Ohnishi, T. Silencing hypoxia-inducible factor- $1 \alpha$ inhibits cell migration and invasion under hypoxic environment in malignant gliomas. Int. J. Oncol. 2007, 30, 793-802. [CrossRef]

241. Greenberger, L.M.; Horak, I.D.; Filpula, D.; Sapra, P.; Westergaard, M.; Frydenlund, H.F.; Albaek, C.; Schrøder, H.D.; Ørum, H. A RNA antagonist of hypoxia-inducible factor-1 $\alpha$, EZN-2968, inhibits tumor cell growth. Mol. Cancer Ther. 2008, 7, 3598-3608. [CrossRef] [PubMed]

242. Koh, M.Y.; Spivak-Kroizman, T.; Venturini, S.; Welsh, S.; Williams, R.R.; Kirkpatrick, D.L.; Powis, G. Molecular mechanisms for the activity of PX-478, an antitumor inhibitor of the hypoxia-inducible factor-1 $\alpha$. Mol. Cancer Ther. 2008, 7, 90-100. [CrossRef]

243. Isaacs, J.S.; Jung, Y.-J.; Mimnaugh, E.G.; Martinez, A.; Cuttitta, F.; Neckers, L.M. Hsp90 Regulates a von Hippel Lindauindependent Hypoxia-inducible Factor-1 $\alpha$-degradative Pathway. J. Biol. Chem. 2002, 277, 29936-29944. [CrossRef]

244. Voit, R.A.; Sankaran, V.G. Stabilizing HIF to Ameliorate Anemia. Cell 2020, 180, 6. [CrossRef]

245. Bai, W.-W.; Xing, Y.-F.; Wang, B.; Lu, X.-T.; Wang, Y.-B.; Sun, Y.-Y.; Liu, X.-Q.; Guo, T.; Zhao, Y.-X. Tongxinluo Improves Cardiac Function and Ameliorates Ventricular Remodeling in Mice Model of Myocardial Infarction through Enhancing Angiogenesis. Evidence-Based Complement. Altern. Med. 2013, 2013, 1-9. [CrossRef] [PubMed]

246. Liu, X.-W.; Lu, M.-K.; Zhong, H.-T.; Wang, L.-H.; Fu, Y.-P. Panax Notoginseng Saponins Attenuate Myocardial IschemiaReperfusion Injury Through the HIF-1 $\alpha$ /BNIP3 Pathway of Autophagy. J. Cardiovasc. Pharmacol. 2019, 73, 92-99. [CrossRef] [PubMed]

247. Jain, T.; Nikolopoulou, E.A.; Xu, Q.; Qu, A. Hypoxia inducible factor as a therapeutic target for atherosclerosis. Pharmacol. Ther. 2018, 183, 22-33. [CrossRef] [PubMed] 
248. Ahmad, A.; Ahmad, S.; Malcolm, K.C.; Miller, S.M.; Hendry-Hofer, T.; Schaack, J.B.; White, C.W. Differential Regulation of Pulmonary Vascular Cell Growth by Hypoxia-Inducible Transcription Factor-1 $\alpha$ and Hypoxia-Inducible Transcription Factor-2 $\alpha$. Am. J. Respir. Cell Mol. Biol. 2013, 49, 78-85. [CrossRef] [PubMed]

249. Dai, Z.; Zhu, M.M.; Peng, Y.; Machireddy, N.; Evans, C.; Machado, R.; Zhang, X.; Zhao, Y.-Y. Therapeutic Targeting of Vascular Remodeling and Right Heart Failure in Pulmonary Arterial Hypertension with a HIF-2 $\alpha$ Inhibitor. Am. J. Respir. Crit. Care Med. 2018, 198, 1423-1434. [CrossRef] 